\title{
UNCONSTITUTIONALLY ILLEGITIMATE DISCRIMINATION
}

\author{
Brandon L. Garrett* \\ University of Virginia School of Law \\ 580 Massie Road \\ Charlottesville, VA 22903-1738 \\ (434) $924-4153$ \\ bgarrett@virginia.edu
}

February 12, 2018

(C) Brandon L. Garrett, 2018

* White Burkett Miller Professor of Law and Public Affairs and Justice Thurgood Marshall Distinguished Professor of Law, University of Virginia School of Law. Many thanks to Kerry Abrams, Eric Berger, Kevin Cope, Mike Dorf, Richard Fallon, Mark Graber, Deborah Hellman, Aziz Huq, Dayna Matthews, George Rutherglen, Micah Schwartzman, Fred Schauer, Gregg Strauss, and Annie Woolhandler for their invaluable comments on drafts. 


\title{
UNCONSTITUTIONALLY ILLEGITIMATE DISCRIMINATION
}

\begin{abstract}
When government officials express intent to disparage or discriminate against a group, the constitutional consequences can be severe, but they are rarely imposed. In this Article, I argue that discriminatory motive is and should be enough to declare government acts unconstitutional. Second, I argue that the main reason why is the harm to government legitimacy. While some argue that the concern with intentional discrimination is its harm, such as its stigmatizing effect, I argue that the focus should not be on harm, but on how it delegitimizes government. I make the descriptive claim that Constitutional doctrine, in its broad outlines, reflects a legitimacybased view. In the Equal Protection context, courts have set out how discriminatory goals are not legitimate state interests. In the Executive action context, courts state that absent a legitimate and bona fide justification, the Executive may not have power delegated from Congress to act. What courts have not done is specified what happens when the hammer falls: how intent disables government policymaking and for how long. The legitimacy-focused approach can neutralize government decisions, even when the government tries to re-do its policy and claim new reasons. Third, I argue that a legitimacy-focused approach towards constitutional intent doctrine that I advance in this Article is normatively preferable. The approach does incentivize insincere reasons for government actions. However, I argue that advantages outweigh those costs. There are real benefits to even insincere expressions of non-discrimination. Conversely, when the government makes discriminatory statements, this is very strong evidence of discriminatory motive. During a time of nationwide litigation of intentional discrimination claims in areas including immigration rights, voting rights, and religious non-establishment, it has never been more important to set out the doctrine, the costs, and the consequences of unconstitutionally illegitimate intent.
\end{abstract}




\section{TABLE OF CONTENTS}

INTRODUCTION

$\begin{array}{lr}\text { I. WHY INTENT? } & 6\end{array}$

A. Legitimacy in Constitutional Doctrine $\quad 7$

B. Discriminatory Intent Doctrines 12

1. Purpose Under the First Amendment 12

2. Animus, Intent, and Purpose Under the Equal 13 Protection Clause

3. Discriminatory Intent and Voting Rights 15

4. Discriminatory Intent and the Sixth Amendment 16

5. Dormant Commerce Clause and Purpose 17

6. Bad Faith Executive Action 18

C. The Harm and the Cost of Discriminatory Intent 18

D. Defining Intent 20

E. From Harm to Cost 24

II. The EFFECTS OF DisCRIMINATORY INTENT ON LEGITIMACY 26

A. Undermining Government Defenses 28

B. Promoting Nondiscriminatory Government 31

C. Undermining Government Power 33

III. REMEDYING THE EFFECT OF DisCRIMINATION 35

A. Persistence of the Effect 36

B. Remedies for Discrimination $\quad 37$

C. Anti-Discrimination Statutes 39

$\begin{array}{lr}\text { CONCLUSION } & 40\end{array}$ 


\section{UNCONSTITUTIONALLY ILLEGITIMATE DISCRIMINATION}

\section{INTRODUCTION}

If the government itself makes disparaging statements about a group of people, that alone should be enough to render government action unconstitutional. That principle should be straightforward. However, courts have not been clear about either the consequences of discriminatory intent or the reasons why intent matters. In this Article, I show why discriminatory intent has systematically corrosive effects on government legitimacy. I argue that a legitimacy-based approach should be foundational in constitutional anti-discrimination doctrine. As Justice Sandra Day O'Connor put it, "disapproval of a group cannot be a legitimate government interest." Judges do not casually make findings of unconstitutional intent, since doing so can disable the government actors from making policy at all-but imposing those severe consequences can also help to prevent even greater social harm.

Take as an example the Alabama Constitution, which in 1901 was amended to include a provision disenfranchising any person convicted of a crime of "moral turpitude." ${ }^{2}$ In 1985, the U.S. Supreme Court, with Chief Justice William Rehnquist writing a unanimous opinion in Hunter $v$. Underwood, concluded that although over eighty years had passed, the amendment was enacted with the intent to disenfranchise black voters. ${ }^{3}$ Alabama lawmakers admitted their goal was to "establish white supremacy," and they selected a wide range of serious and petty crimes believed "to be more frequently committed by blacks." 4 The harm was not just the ugly view expressed by the measure. The harm was not just the direct impairment of voters' rights. Indeed, the harm to victims does not fully captured the constitutional problem - which was systemic and structural. The cost was to the legitimacy of democracy in the state of Alabama. One goal of this Article is to set out more fully the scope the cost of intentional discrimination.

A decade after the Justices struck down that amendment, Alabama adopted enacted a new "moral turpitude" amendment, applying this time only to felonies. Thus far, challenges to the new voting restriction have failed. Should they?

Judges sometimes note that action tainted by unconstitutional intent might be valid if it were to be hypothetically enacted today absent that taint. The Justices suggested as much in dicta in the Hunter decision. ${ }^{6}$ What if the

\footnotetext{
${ }^{1}$ Lawrence v. Texas, 539 U.S. 558, 581 2003) (O'Connor, concurring) (referring to "moral disapproval" of a group; the focus here is on intentional discrimination more broadly).

2 Ala. Const. of 1901, art. VIII, § 182.

3471 U.S. 222, 226 (1985).

${ }^{4} \mathrm{Id}$.

${ }^{5}$ See Chapman v. Gooden, 974 So. 2d 972, 976 (Ala. 2007).

6471 U.S. at 232 .
} 


\section{UNCONSTITUTIONALLY ILLEGITIMATE DISCRIMINATION}

action, though, is re-enacted to try to "cure" the taint of unconstitutional intent? Such rulings raise the question: when government officials express discriminatory intent or disapproval of groups of people, what should be the full set of constitutional consequences? A stronger appreciation for the systematic and structural cost of discrimination can help one to better answer such questions. This Article seeks to explore those challenging questions by proposing a new test that focuses the analysis not on the harm to victims, or even to the general public, but on the effect of intentional discrimination on the legitimacy of government itself. I argue that the cost to legitimacy, reflected in some but certainly not all of the doctrine, should be the primary focus of constitutional analysis.

The cost of discriminatory bias infecting government action, whether it is a criminal trial, an immigration order, a local regulation, or a federal statute, can be so great that the Supreme Court has held official action to a very different standard with unconstitutional intent or purpose is invoked. The Court has set out a complex intent standard in its Equal Protection Clause doctrine-one that is neither purely objective or subjective and with several factors that give judges a great deal of discretion. ${ }^{7}$ Many have raised the concern that intent or purpose standards can be used to sweep discrimination under the rug, since it is often difficult to show that officials acted with the requisite intent. 8 Discriminatory intent doctrine has been widely seen as a judicial tool to limit anti-discrimination remedies. Without disagreeing with those concerns, in this Article I acknowledge that the doctrine may reward superficial or even insincere expression of neutrality or non-discriminatory intent. Such expressions can also have an important and underappreciated function, however. The doctrine pushes government away from corrosive and disparaging statements and towards reasoned policymaking. This is the legitimacy-building function of intent doctrine.

We should revisit the importance of strongly incentivizing legitimacy, including through neutral public statements that do not disparage groups. There is great value, I argue, to sweeping such discrimination out of public discourse. One hopes that government decisionmakers would not often outright admit that they acted based on invidious intent. However, when politics do become divisive, and we have entered an era of extreme partisan

\footnotetext{
7 See, e.g. Daniel R. Ortiz, The Myth of Intent in Equal Protection, 41 Stan. L. Rev. 1105, 1113-14 (1989); David Strauss, Discriminatory Intent and Taming of Brown, 59 U CHI. L. REv. 935, 947 (1989); Michael Selmi, Proving Intentional Discrimination: The Reality of Supreme Court Rhetoric, 86 GEO. L. REV. 279 (1997); Aziz Z. Huq, Judging Discriminatory Intent, 103 CoRnell L. REV. _- (2017); Russell K. Robinson, Unequal Protection, 68 STAN. L. REV. 151 (2016).

8 Suzanne Goldbert, Discrimination by Comparison, 120 YALE L. J. 728, 728 (2011); Chad Derum \& Karen Engle, The Rise of the Personal Animosity Presumption in Title VII and the Return to "No Cause" Employment, 81 TEx. L. REV. 1177, 1207 (2003) (noting that "no sensible employer would admit that it based a decision on one of the prohibited classifications").
} 


\section{UNCONSTITUTIONALLY ILLEGITIMATE DISCRIMINATION}

polarization in the United States, ${ }^{9}$ if not also inter-group conflict, ${ }^{10}$ judges may increasingly confront claims of discriminatory intent by government.

Active national litigation over voting rights, immigration rights, and religious non-establishment all implicates questions of discriminatory intent. This Term, for example, the Supreme Court remanded for further proceedings in a case involving racially discriminatory views by a juror in a death penalty case. ${ }^{11}$ The Court initially scheduled arguments concerning a claim that the President's remarks signaled intent to discriminate based on religion and ethnicity, before dismissing the suit as mooted; the Court has now scheduled arguments on a new round of such litigation. ${ }^{12}$ In the past Term, the Justices granted relief in a challenge to the use of race in districting, ${ }^{13}$ and in a jury discrimination case, calling the impact of racial bias among jurors "a familiar and recurring evil that, if left unaddressed, would risk systemic injury to the administration of justice." ${ }^{14}$ National litigation concerning voting rights, immigration orders, and religious discrimination, continues to raise claims of discriminatory intent. ${ }^{15}$ This Article argues that intent matters in such litigation specifically because of the de-legitimizing effect it has on government action.

In some constitutional contexts, the Supreme Court has been clear why discriminatory intent is forbidden: because it has a system-wide delegitimizing effect. The Court has been quite clear that "slurs" or government actions that "disparage or injure" are strongly disfavored if not prohibited under the Equal Protection Clause, as well as under other constitutional provisions such as the First Amendment regarding the Establishment Clause and Free Exercise Clause ${ }^{16}$; and the Fifteenth Amendment regarding voting rights discrimination. ${ }^{17}$ As the Court noted in

\footnotetext{
9 See generally, Richard H. Pildes, Why the Center Does Not Hold: The Causes of Hyperpolarized Democracy in America, 99 CAL. L. REV. 273 (2011).

10 On increased racial polarization among American voters, see, e.g. Leading Case, Fourteenth Amendment-Equal Protection Clause-Racial Gerrymandering-Cooper v. Harris (2017).

11 Tharpe v. Sellers, 2018 WL 311568.

12 Trump v. International Refugee Assistance Project, 137 S. Ct. 2080, 2086 (2017) (per curiam); Trump v. Hawaii, 2018WL 324357 (January 19, 2018) (cert. granted).

${ }^{13}$ Cooper v. Harris, 581 U.S. __ (2017).

14 Pena-Rodriguez v. Colorado, 137 S.Ct. 855, 868 (2017).

15 For a summary of ongoing voting access litigation, see Brennan Center for Justice, Major Litigation that Could Impact Voting Access (last visited on Nov. 27, 2017), at https://www.brennancenter.org/major-litigation-could-impact-voting-access. For a detailed summary and timelines of the Executive Order litigation regarding the three travel ban orders, see NAFSA, Executive Order Entry Ban Litigation Update, Nov. 21, 2017, at http://www.nafsa.org/Professional_Resources/Browse_by_Interest/International_Students_an d_Scholars/Executive_Order_Entry_Ban_Litigation_Updates/.

16 Wallace v. Jaffree, 472 U.S. 38, 43, 56 (1985) (Establishment Clause); Church of the Lukumi Babalu Aye, Inc. v. City of Hialeah, 508 U.S. 520, 533 (1993) (Free Exercise Clause).

17 E.g. League of United Latin American Citizens v. Perry, 548 U.S. 399, 440 (2006).
} 


\section{UNCONSTITUTIONALLY ILLEGITIMATE DISCRIMINATION}

City of Richmond, "gross racial slurs" intended to single out black citizens can be forbidden and have "no legitimacy at all under our Constitution."18 The focus is not on how long the harm lasts or what type of harm it is. The purpose is to delegitimize action premised on such slurs. Such language supports my view in this Article. Or, as the Court has put it in the First Amendment context, the concern is with expression of "hostility" towards religion. ${ }^{19}$ Constitutional rules debilitating government action based on disparagement directed at groups serve to strongly discourage such intent from expression. The Court has noted that the hope is that such tests are not often "fatal" because government fortunately "does not generally act unconstitutionally." 20 Recent rulings have revived the role of intent in cases involving due process and equal protection claims. For example, Obergefell $v$. Hodges emphasized denial to same-sex couples of the right to marry expressed "disapproval of their relationships" and "serves to disrespect and subordinate them." ${ }^{21}$ In United States $v$. Windsor, the Court highlighted legitimacy concerns still more powerfully, stating that "no legitimate purpose overcomes the purpose and effect to disparage and to injure those whom the State, by its marriage laws, sought to protect in personhood and dignity." 22

As I describe in Part I of this Article, the doctrine in a wide range of constitutional contexts regarding explicit claims of discrimination based on race, religion, gender identity and many others, whether referred to as a claim of an unconstitutional intent, purpose, animus claims, or "rational basis with bite," reflects a framework to handle a wide range of situations in which officials make discriminatory decisions. ${ }^{23}$ In Part I of this Article, I summarize that caselaw and surrounding doctrine, but I focus on the doctrine concerning the effect of evidence of unconstitutional intent on the government. I do not seek to engage with questions regarding what the definition of intent is or should be under the Equal Protection Clause, or for other constitutional and statutory discrimination claims. While I agree with many scholars that any definition should include both subjective and objective evidence of discriminatory intent, the focus here is not on evidence, nor on questions such as how to prove intent for multi-member bodies that deliberate. ${ }^{24}$ I argue that questions of definition and evidentiary proof, while

\footnotetext{
${ }^{18}$ City of Richmond v. U.S., 422 U.S. 369, 378-79 (1975).

${ }^{19}$ Lynch v. Donnelly, 465 U.S. 668, 673 (1984).

20 McCreary County v. ACLU of Ky, 545 U.S. 844, 863 (2005).

21135 S.Ct. 2584, 2604 (2015). See also U.S. v. Windsor, 133 S.Ct. 2675, 2696 (2013) ("no legitimate purpose overcomes the purpose and effect to disparage and to injure those whom the State, by its marriage laws, sought to protect in personhood and dignity.") For discussion of the role of public reason in the decision, see, e.g. Robert Katz, The Role of Public Reason in Obergefell v. Hodges, 11 FIU L. REV. 177 (2015).

22 U.S. v. Windsor, 133 S.Ct. 2675, 2696 (2013).

${ }^{23}$ See infra Part I.A.

${ }^{24}$ See, e.g. Richard H. Fallon, Jr., Constitutionally Forbidden Legislative Intent, 130 HARV. L. REV. 523, 530-31 (2016) ("I do not analyze the partly parallel problems that arise when
} 


\section{UNCONSTITUTIONALLY ILLEGITIMATE DISCRIMINATION}

important in the law of discriminatory intent, are preceded by the overarching goal of intent doctrines: to prevent the institutionally corrosive effect of intentional discrimination on government. We should all be able to agree that disparaging statements by government are unconstitutional.

Second, I argue that the reason why is legitimacy. The message matters because of what it says about the speaker. In Part I, argue that discriminatory statements may damage the government official far more than any others. Importantly, the cost of disapproval and disparagement of groups is itself extremely broad and hard to cabin. Branding a group of persons can cause legal and expressive harms beyond the particular group singled out and beyond the particular government action at issue. I argue that the systemic cost explains why the consequences can be severe.

In Part II, I develop how a legitimacy-focused inquiry has structural implications for government, First, I develop how evidence discriminatory intent can undermine government defenses to a constitutional claim. Second, I develop how a legitimacy-based approach towards discriminatory intent incentivizes neutral and non-discriminatory government action. Third, I argue that evidence of ill intent can help with an argument that the government has exceeded the bounds of its structural power to act. Normally, the Court favors "government statements of purpose" that are benign, because we want the government to speak in a non-disparaging way. If the government departs from that stance, though, then it will not easily defend its actions. Going still farther, in a set of areas, the government may lose far more: acting in an intentionally disparaging way may place the government's actions outside of the limits of its constitutionally recognized power. Its actions may be constitutionally illegitimate. Rulings regarding the non-enumerated "plenary" immigration power have this character, since the implied power to regulate entry into the country at the federal level exists only when not in conflict with other constitutional powers and limits.

Part III turns to questions of what happens when the hammer falls: how much the government can lose legitimacy, for how long, in what circumstances, and with what constitutional implications. I argue that at minimum, it is strong evidence of discriminatory intent when the government makes disparaging statements. I develop how when the government does so, the consequences can be severe: government actors may be forbidden from carrying out their policies, and for quite some time, since courts may be loath

single officials--such as prosecutors, other executive officials, or judges--act for constitutionally forbidden purposes."); John Hart Ely, Legislative and Administrative Motivation in Constitutional Law, 79 YALE L.J. 1205 (1970). That problem is not the focus here. Nor is the focus on what happens when policymakers base decisions on "naked preferences" that disadvantage others, as Cass Sunstein has put it. Cass Sunstein, Naked Preferences and the Constitution, 84 Colum. L. REV. 1689 (1984). Instead, the focus is on the de-legitimizing effect of discriminatory intent, if it is proven, and what impact it has on government action. I discuss Richard Fallon's arguments in Parts I and II. 


\section{UNCONSTITUTIONALLY ILLEGITIMATE DISCRIMINATION}

to trust their motives if they quickly claim to have re-done the policy claiming newly clean hands. The taint of constitutionally illegitimate intent may persist so long as the relevant action is taken. As the Supreme Court has put it, "the world is not made brand new every morning." 25 The intent may impugn the motives of the speaker and undermine any non-discriminatory reasons offered to defend government action, including because they may place the action beyond the power of the government to act.

This Article concludes by developing why "purpose matters," not just because ill-intent harms, but because it is corrosive of government legitimacy. ${ }^{26}$ It is so corrosive that the government cannot quickly repair that legitimacy. The blunt instrument of intent doctrine accomplishes an important goal: to exile discriminatory statements from public discourse and decisionmaking. I argue courts rightly impose grave constitutional consequences on government actors that act outside legitimate bounds. What is good public policy can and should be disputed. However, disparaging groups is never acceptable as legitimate government. Intent standards have practical limitations, and critics are right to point to difficulties in defining and proving intent. The underappreciated virtue of the doctrine is that it seeks to banish explicit discrimination from public life. Although intent standards can be vaguely defined, that too can carry with it the virtue of deterring extremely damaging conduct. In an increasingly pluralistic society, it is particularly important to ensure that groups do not use the law to establish status hierarchy. The doctrine of unconstitutionally illegitimate intent is important in modern democracies as never before.

\section{WHY INTENT?}

Why does intent matter in so many areas of constitutional law? For decades, the Supreme Court has often found unconstitutional laws that express a denigrating or discriminatory purpose. In Brown v. Board of Education, the Court emphasized how "[s]eparate educational facilities are inherently unequal." 27 The Court did not discuss whether the discrimination was intentional or not, and when ruling on de jure discrimination, it did not need to do so. The focus on intent or purpose on constitutional standards, whether in the Equal Protection context, or in other contexts, such as the First Amendment, Dormant Commerce Clause, or the Sixth Amendment, would emerge later, beginning in the 1970s. During that time, scholars first began to grapple with when and whether intent or purpose or motive should matter in constitutional law. There is a large literature on the evidentiary challenges of assessing intent, particularly for collective bodies like legislatures. There is a large literature on how to define unconstitutional

${ }^{25}$ McCreary, 545 U.S. at 866.

26 Id. at n.14.

${ }^{27}$ Brown v. Board of Educ., 347 U.S. 483, 493 (1954). 


\section{UNCONSTITUTIONALLY ILLEGITIMATE DISCRIMINATION}

intent or purpose. There is less analysis of why intent might matter in the first instance. That is the focus of this Part.

Asking why intent matters may initially "seem silly." 28 One important and neglected reason why intent matters is because government action that intentionally discriminates is itself illegitimate: it cannot be justified as in the public interest, not just because it harms groups but because it is not in the public interest to demean or disparage a group. In this Part, I defend the idea that whatever discriminatory intent means, it is enough to declare government action unconstitutional.

I begin by describing what the theory is of legitimacy that animates this project and why legitimacy of government policy and action matters as a background principle in constitutional law. Second, I turn to intent doctrine in constitutional law and the role that legitimacy plays in it. Third, I describe how despite differing definitions of intent and purpose in constitutional law, a common focus on legitimacy remains in the doctrine. Fourth, I contrast the view of intent and legitimacy with theories of expressive harm in constitutional law.

\section{A. Legitimacy in Constitutional Doctrine}

The Supreme Court has emphasized across a range of constitutional doctrines that the harm of purposeful or intentional acts directed at groups is that they de-legitimize government and harm society broadly. Quite a bit of scholarship treats intent as an evidentiary issue; for example, Richard Fallon's recent article takes as its starting place the concern that in existing doctrine, the problem is that the courts have set out "varied approaches to the identification of legislative intent." 29 That is, the scholarship assumes that the problem is whether a plaintiff can make out a constitutional violation. Intent by government officials, under such an approach, serves an evidentiary function: it is something that must be shown in order to make out a claim that the constitution was in fact violated. When the assumption is that intent serves an evidentiary and instrumental role, then unsurprisingly, the question turns to the challenges of securing the evidence to prove the relevant type of intent. The main focus, then, for Fallon, is the area in which there is the greatest evidentiary challenge, in his view, and that is in gauging intentions of multimember legislative bodies. ${ }^{30}$

If, however, the purpose served by intent or purpose tests is different and not simply evidentiary, then the doctrine does not pose the same problems. In this Article, I focus on a different conception of the role that intent plays in the doctrine can: discriminatory intent is itself a constitutional evil. Intent, purpose, animus, or whatever the label, does not

\footnotetext{
${ }^{28}$ William D. Araiza, Animus: A Short Introduction to Bias in Law 2 (2017).

${ }^{29}$ Fallon, supra note xxx at 530-31.

${ }^{30}$ Id. at 530.
} 


\section{UNCONSTITUTIONALLY ILLEGITIMATE DISCRIMINATION}

serve purely an evidentiary role in smoking out government action and identifying it as truly discriminatory. There are challenges in obtaining evidence of discriminatory intent and there are challenges in defining discriminatory intent. It is useful to explore those challenges in legal scholarship and in the courts. However, intent standards serve a different and more fundamental role. Discriminatory intent, whether it is indicative of underlying goals or not, is itself de-legitimizing. It itself is an illegitimate reason for government to act. If discriminatory intent impacts legitimacy, that raises a preliminary and more fundamental question: what does legitimacy mean in the context of Government action, whether legislative or regulatory or enforcement related?

The concept of legitimacy refers to some bound of permissible publicly interested action. Public reason theories of government, following the work of John Rawls, develop in detail a moral account of government action requiring that there be a public-minded and reasoned basis for government decisionmaking. ${ }^{31}$ Rawls emphasized in his work that "[p]ublic reason is characteristic of a democratic people: it is the reason of its citizens [as such], of those sharing the status of equal citizenship." 32 A central principle in that work is that of legitimacy. ${ }^{33}$ Public reason requires some notion of reciprocity, or enacting measures that all free citizens might also reasonably endorse as desirable. Action that grossly harms the public may not be illegitimate if it is within the discretion of government officials; government officials do not need to make wise and sound policy choices. However, actions that are sound policy choices, conversely, may be illegitimate if adopted for purely religious reasons. The contours of what counts as government actions based on public reason and which do not, under Rawl's theory or those of other moral philosophers, are well beyond the scope of this project, as are critiques of Rawl's theory of legitimacy and public reason. ${ }^{34}$

What is straightforward under accounts of public reason is that discriminatory actions are not legitimate and not supported by public reason. As William Araiza puts it, government "at least has to seek to promote a public purpose." It is clearly not legitimate and not tolerable to harm people "just because a political majority doesn't like them." 35 Discriminatory action that is intended to harm groups of citizens is highly corrosive and is treated across a range of contexts as different from routine policy choices that

\footnotetext{
31 John Rawls, Political Liberalism (1996). See also id. at 136 (“[O]ur exercise of political power is fully proper only when it is exercised in accordance with a constitution the essentials of which are all citizens as free and equal may reasonably be expected to endorse in light of principles and ideals acceptable to their common human reason.").

32 Id. at 213.

33 Id. at 137.

${ }^{34}$ See, e.g. Elizabeth H. Wolgast, The Demands of Public Reason, 94 Colum. L. Rev. 1936 (1994). Regarding which officials are bound by public reason, see Lawrence Solum, Public Legal Reason, 92 Virginia L. Rev. 1449, 1476-78 (2006).

35 Araiza, supra note xxx at 2.
} 


\section{UNCONSTITUTIONALLY ILLEGITIMATE DISCRIMINATION}

incidentally advantage some and disadvantage others. As John Hart Ely has put it: "To disadvantage a group essentially out of dislike is surely to deny its members equal concern and respect, specifically by valuing their welfare negatively." 36 There is also a larger moral question whether judicial review is broadly necessary for action that is not supported by public reason and is therefore illegitimate. Micah Schwartzman has convincingly argued as much, using as the frame of reference John Rawl's conception of public reason. ${ }^{37}$ Schwartzman argues that courts should properly ask about the motivations of public actors and whether their actions are supported by public goals, as opposed to, for example, desire to discriminate. ${ }^{38}$

This concept of legitimacy mirrors the conception of the common good underlying James Madison's theory of sound republican government in the Federalist. ${ }^{39}$ Madison argued that the entire design of the Constitution sought to "restrain" as against "legal discriminations" the corrupting influence of "factions," in which a group acted against or in favor of "a particular class of the society." 40 As Madison put it at the Constitutional Convention, the "injustice" to be prevented was that of "the majority trampling on the rights of the minority." 41 Madison described as examples of such "injustice," legislation that exhibited "partiality," because it would create inequality, or it would be adverse to "aggregate interests of the community." 42 According to Madison, this danger, that of "faction," was the central danger faced by democracy: the "mortal disease. . . of republican government, unless it is carefully controlled." 43 The U.S. constitutional structure, as Howard Gillman has described, was intended to "preempt" factional politics and encourage the view that "legitimate government exercised power disinterestedly to advance a transcendent general welfare." 44 Madison himself, however, was not satisfied that the constitutional design did enough to protect against oppression of minority groups at the state level, particularly. Madison pushed throughout the Constitutional Convention for the adoption of a "negative" permitting a federal revision commission to strike down state legislation that abused minority rights, but was

\footnotetext{
36 John Hart Ely, Democracy and Distrust at 157.

${ }^{37}$ Micah Schwartzman, Must Laws be Motivated by Public Reason? (draft on file with author).

38 Id.

${ }^{39}$ For a detailed development of those ideas, see James Liebman and Brandon L. Garrett, Madisonian Equal Protection, 104 CoLUM. L. REV. 807 (2004).

40 The Federalist, No. 10, 62 (James Madison).

${ }^{41}$ See James Madison, Debates at the Virginia Convention (June 6, 1788), in 9 The Documentary History of the Ratification of the Constitution 989, 989-990 (John P. Kaminski \& Gaspare J. Saladino eds., 1990).

42 The Federalist No. 51, 78 (James Madison).

43 The Federalist, No. 10, 77 (James Madison).

${ }^{44}$ Howard Gillman, The Constitution Beseiged (1993).
} 


\section{UNCONSTITUTIONALLY ILLEGITIMATE DISCRIMINATION}

unsuccessful in convincing fellow delegates of the merits the approach. ${ }^{45}$ The Bill of Rights and the Equal Protection Clause of the Fourteenth Amendment, go farther towards realizing the Madisonian vision of an additional check as against discriminatory state and local action that harms minorities. ${ }^{46}$ Whether the Equal Protection Clause in particular does enough to safeguard minority rights has depended on the degree to which the courts enforce it carefully. ${ }^{47}$ The dependence in our system on judicially-enforced rights to safeguard minority rights makes it all the more important that judges have the right concept of legitimacy underlying their work.

The concept of legitimacy used throughout this Article is a moral concept of legitimacy. In an important article, Richard Fallon has usefully broken out several concepts of legitimacy that are relevant to constitutional law. ${ }^{48}$ As a legal concept legitimacy refers to compliance with legal norms. ${ }^{49}$ A sociological concept of legitimacy refers to acceptance of a constitutional claim by the public, or relatedly, acquiescence in that claim. ${ }^{50}$ The moral concept of legitimacy that I discuss here is focused on the moral justification for a claim of constitutional authority. ${ }^{51}$ The difference can sometimes matter for the arguments discussed in this Article. For example, if it is a sociological fact that many people espouse a racially discriminatory view, for example in favor of segregation, then that may affect sociological arguments that courts should be reluctant to interfere with public opinion, but they are not relevant to claims of moral legitimacy. Or a claim that an approach is

\footnotetext{
${ }^{45}$ See Liebman and Garrett, supra note 38.

46 See id.

47 See id. (arguing that even the Equal Protection Clause of 1868 did not sufficiently structure protections against oppressive state action).

48 Richard H. Fallon, Legitimacy and the Constitution, 118 HARV. L. REV. 1187 (2005).

$49 \mathrm{Id}$. at 1187.

${ }^{50} \mathrm{Id}$. at 1187. In this Article, I do not develop the implications of a sociological concept of legitimacy. Such a focus would not, in my view, track much of constitutional intent doctrine. However, an approach relying on sociological legitimacy would have certain benefits. It would be more grounded in social fact, and it might help to explain compliance with the law that psychologists have shown can sometimes be affected by perceptions of legitimacy as a factor. See, e.g. Tom Tyler, Psychological Perspectives on Legitimacy and Legitimation, 57 Ann. Rev. Psychol. 375 (2006); Tom Tyler, Why People Obey the Law (2006). Such an approach, however, would require careful empirical investigation of public attitudes. See, e.g. Aziz Z. Huq, Jonathan Jackson, and Rick Trinker, Acts that Legitimate: Widening the Array of Predicate Policing Practices (2016), at https://papers.ssrn.com/sol3/papers.cfm?abstract_id=2740631 (developing broader array of practices that impact individual assessment of the legitimacy of police). Such an approach would then require asking questions about what types of discriminatory government action created reduction in public support for government. Further, where it is minority rights that are the target, then majority views may correctly be irrelevant social facts to a claim of discrimination.

${ }^{51}$ Fallon, supra note xxx, at 1187.
} 


\section{UNCONSTITUTIONALLY ILLEGITIMATE DISCRIMINATION}

consistent with legal precedent may satisfy legal legitimacy concerns, but not moral legitimacy concerns. ${ }^{52}$

A clarification in that literature is also important to the argument I develop in this Article. Matthew Adler has argued that constitutional rights are "rights against rules," and have derivative moral content giving people a right to be free from government action based on a rule that is morally problematic. ${ }^{53}$ The focus is not on whether a "moral wrong" was done to the plaintiff, but rather on the moral reason to change the rule that government actors relied upon. ${ }^{54}$ As I develop in this Article, the focus on the legitimacy of government places the emphasis on the moral status of government, and not on the harm, expressive or otherwise, to individuals. This also has implications for how rights are litigated; if they are conceived more as shields against particular actions or rules (Adler's argument is about rules) then doctrines regarding standing and remedies may also have to be reconsidered.

Whether it is morally required that courts take such a view regarding legitimacy and public reason, a topic that I do not address, it is descriptively accurate to say that the U.S. Constitution supports judicial review designed to assess the motivations of public actors. ${ }^{55}$ In a range of constitutional contexts, the Supreme Court has asked courts to do precisely that. The Court has highlighted how "moral disapproval of a group cannot be a legitimate government interest." 56 The next subsections turn to that doctrine.

\section{B. Discriminatory Intent Doctrines}

Constitutional doctrine and theory recognize that discriminatory acts targeting groups by virtue of their group membership are not acceptable as public policy. The problem of discriminatory intent is not limited to the problem that intent is manifested in subjective but hard-to-pin-down motivations of the relevant actors, and nor that the message conveyed is hurtful to the group itself. Nor is the only problem that discriminatory intent is defined poorly and hard to prove. Nor is the problem of discriminatory intent that it harms individuals, through outcomes, or stigmatizing expression. Rather, I argue, the central problem that should be the focus of doctrine is the corrosive effect on government itself of having acted based on discriminatory reasons. An analysis of relevant areas of constitutional

\footnotetext{
52 Regarding the need for authority to be both just and legitimate, see John Simmons, Justification and Legitimacy, 109 Ethics 739, 752-53 (1999).

${ }^{53}$ Matthew D. Adler, Rights Against Rules: The Moral Structure of American Constitutional Law, 97 Mich, L. REV. 1, 3-4 (1998).

${ }^{54} \mathrm{Id}$.

${ }^{55}$ See, e.g. John Ferejohn and Barry Friedman, Toward a Political Theory of Constitutional Default Rules, 33 FLA. ST. U. L. REV. 825, 836 (2006) ("The idea that policy ought to be grounded in reason, perhaps in public reason, may also ground certain constitutional defaults.").

56 Lawrence v. Texas, 539 U.S. 558, 581 2003) (O’Connor, concurring).
} 


\section{UNCONSTITUTIONALLY ILLEGITIMATE DISCRIMINATION}

doctrine can help to explain that underlying function of intent rules, although I will point out how not all doctrine is consistent with my approach, given the complex and evolving uses of intent in different constitutional areas.

My goal in the sections to follow is to excavate the central role of (moral) legitimacy in discriminatory intent doctrine. I make the descriptive claim that constitutional doctrine reflects the legitimacy based review advanced here, in (1) First Amendment doctrine, including the Establishment Clause; (2) Equal Protection doctrine, including the doctrines of unconstitutional animus and purpose; (3) voting rights cases; (4) Sixth Amendment jury discrimination claims; (5) Dormant Commerce Clause; and (6) the structural doctrine of bad faith Executive action.

\section{Purpose Under the First Amendment}

At times the Justices have raised evidentiary concerns with fixing the motivations of legislators. In United States v. O'Brien, Chief Justice Earl Warren explained that "Inquiries into congressional motives or purposes are a hazardous matter," and might involve voiding a statute based on "what fewer than a handful of Congressmen said about it." 57 Moreover, perhaps lawmakers could reenact the law "in its exact form if the same or another legislator made a 'wiser' speech about it." 58 However, in the First Amendment setting, the Supreme Court has largely abandoned that concern and proceeded to make inquiry into motivation, or intent, a central feature of the doctrine. ${ }^{59}$

Take the Establishment Clause. The problem of religious preferences is not just that one religious group benefits and one comparatively suffers, although the concern with religious persecution is important. As the Court has put it, the harm to victims of religious discrimination does not capture the full scope of the problem, which goes to the legitimacy of government itself: the drafters of the First Amendment believed entanglement of government and religion "tends to destroy government and degrade religion."60 Harm is not irrelevant. Part of the concern, to be sure, is with religious persecution and the terrible harm that it causes to persons of the faith that is discriminated against. However, harm is not necessary either. The Court may strike down "relatively insignificant" incursions because any governmental involvement in religion is forbidden by the Constitution. ${ }^{61} \mathrm{In}$ approving a ceremonial town prayer in Town of Greece N.Y. v. Galloway,

\footnotetext{
57391 U.S. 367, 383-84 (1968).

$58 \mathrm{Id}$. at $383-84$.

${ }^{59}$ In the speech context, the law of content-based restrictions on speech expresses a concern with preventing action taken with the purpose of targeting disfavored speech, as now-Justice Elena Kagan has influentially argued. See Kagan, supra note xxx, at 443; see also Reed v. Town of Gilbert, 135 S. Ct. 2218, 2228 (2015) and Fallon, supra note xxx, at 544-45.

60 Engel v. Vitale, 370 U.S. 421, 431 (1962).

61 Id. at 433.
} 


\section{UNCONSTITUTIONALLY ILLEGITIMATE DISCRIMINATION}

Justice Anthony Kennedy emphasized that in no way did the town board members "signal disfavor toward nonparticipants."62 In its Establishment Clause cases, the Court has focused on whether government had a "secular purpose," or rather exhibited "hostility" to a religion. ${ }^{63}$ The purpose of the Establishment Clause is not simply to remedy the harm of religious discrimination, but it serves a larger structural goal. The goal is to prevent illegitimate government action that is derogatory towards one religious group or favoring another. For that reason, under the Establishment Clause doctrine, purpose is understandably more important than the harm or the message sent to particular believers.

\section{Animus, Intent, and Purpose Under the Equal Protection Clause}

In the Fourteenth Amendment Equal Protection Clause context, the focus on discriminatory intent, purpose, and on the legitimacy of government action is central, but with several different tests adopted depending on the type of scrutiny or claim involved. In Loving $v$. Virginia, the Supreme Court adopted a mixed approach, striking down the miscegenation statute because it contained a racial classification, which is presumed unconstitutional, but also because it reflect a legislative purpose to establish "White Supremacy."64 Fifty years later, the Supreme Court continues to adopt a mixed approach, focusing both on presence of racial classifications, but also examining purpose and intent behind government action. ${ }^{65}$

The definition of what consists in discrimination depends on what level of scrutiny applies. For claims of race, religion, national origin, and ethnicity-based discrimination, brought by groups that do have suspect class status for which strict scrutiny applies, the Court held in Washington $v$. Davis that alleging a pattern of discrimination can be enough only if that pattern is quite stark. Typically, one must show a "discriminatory purpose" in order to show an equal protection violation. ${ }^{66}$ The Davis discriminatory purpose requirement was set out in response to evidence that a police qualification exam produced racially disparate results. The Court stated that without more evidence of "discriminatory purpose," that disparate outcomes alone may not suffice to show unconstitutional race discrimination. 67

\footnotetext{
62134 S.Ct. 1811 (2014).

${ }^{63}$ Lynch v. Donnelly, 465 U.S. 668, 673, 684 (1984).

64388 U.S. 1, 11 (1967).

${ }^{65}$ Reva B. Siegel, From Colorblindness to Antibalkanization: An Emerging Group of Decision in Race Quality Cases, 120 YALE L. J. 1278, 1291-93 (2011) (describing the evolution of the relationship between the Court's use of the anticlassification principle in its race equality decisions, and antisubordination principle focused on protecting members of disadvantaged groups from harms).

66 Washington v. Davis, 426 U.S. 229 (1976).

67 Id. at 239.
} 


\section{UNCONSTITUTIONALLY ILLEGITIMATE DISCRIMINATION}

However, the Court made clear that discrimination need not appear on "the face of the statute," and that evidence of application in practice is relevant and can lead to an inference of "invidious discriminatory purpose."68 Cases dating back to Yick Wo v. Hopkins had supported claims based on egregiously disparate government application of the law. ${ }^{69}$ The "totality of the relevant facts" must be considered when deciding whether government action is motivated by "an invidious discriminatory purpose. ${ }^{70}$ Cases regarding race segregation in education cases emphasized, similarly, a showing of de jure segregation, or a "purpose or intent to segregate."71

Subsequent cases have developed how one can make out that showing of discriminatory purpose or intent. In Massachusetts v. Feeney, for example, the Justices more carefully defined what they meant by "discriminatory purpose." The Justice elaborated various factors that are relevant to a finding of discriminatory purpose, and ultimately found that a veteran's preference in civil service hiring was not "overtly or covertly" purposeful gender discrimination despite a quite disproportionate impact on women. ${ }^{72}$ Other recent rulings reflect situations in which actors had multiple reasons to target individuals; in Ashcroft v. Iqbal, the Court emphasized that noncitizens were being detained due to suspected terror ties and not just due to race, religion or national origin. ${ }^{73}$

Those equal protection rulings have been much criticized and they relate to how one defines purpose (is it subjective or objective, and can additional reasons support government action) and what evidence of purpose is relevant (the standard is not purely subjective, since discriminatory impact can be relevant, for example, to the inquiry.) At the same time, scholars in the 1970s, such as Paul Brest and John Hart Ely, prominently began to argue that motive should be relevant to the inquiry whether government engaged in discrimination. ${ }^{74}$ The Justices themselves have expressed an understanding that it is not easy to define discriminatory purpose or what evidence suffices to prove it. For example, in Miller v. Johnson, the Court noted that "[t]he

\footnotetext{
$68 \mathrm{Id}$. at 242.

69118 U.S. 356 (1886).

70 Id. at 242.

71 Keyes v. School Dist. No. 1, 413 U.S. 189, 199 (1973).

72 Mass. v. Feeney, 442 U.S. 256, 271 (1979).

${ }^{73}$ Ashcroft v. Iqbal, 129 S. Ct. 1937, 1951 (2009).

74 See, e.g. Paul Brest, The Supreme Court, 1975 Term - Foreword: In Defense of the Antidiscrimination Principle, 90 HARV. L. REV. 1, 29 (1976) (advocating for motive-based review, but noting that "selective sympathy and indifference" might suffice since "[i]f courts may grant relief only when plaintiffs have made a clear case on the record, many instances will remain where race-dependent decisions are strongly suspected but cannot be proved."); John Hart Ely, Legislative and Administrative Motivation in Constitutional Law, 79 YALE L.J. 1205 (1970); John Hart Ely, Democracy and Distrust: A Theory of Judicial Review 13645 (1980).
} 


\section{UNCONSTITUTIONALLY ILLEGITIMATE DISCRIMINATION}

distinction between being aware of racial considerations and being motivated by them may be difficult to make."75

The Justices have also elaborated a type of intent inquiry for cases in which no strict scrutiny applies. In gender discrimination cases involving an intermediate form of scrutiny, the standard ultimately asks whether there was a purpose to engage in gender discrimination. And in United States Department of Agriculture $v$ Moreno, and cases involving claims of discrimination against groups that do not have "suspect class" status under the Equal Protection Clause, the Court has explained: "a bare congressional desire to harm a politically unpopular group cannot constitute a legitimate governmental interest."76

Those rulings have also been criticized from a range of perspectives as not providing sufficiently clear or protective standards. One central concern is that these purpose or intent doctrines do not end race, gender, or other group-based discrimination, but rather, as Reva Siegel puts it, can cause "such regulation to assume new form." 77 Or as David Baldus and colleagues put it, the Supreme Court's decision in McCleskey $v$. Kemp finding insufficient showing of discriminatory "purpose" in substantial data they analyzed concerning death sentencing in Georgia, was part of "a long tradition of Supreme Court decisions imposing unattainable burdens of proof in order to deny and avoid claims of racial discrimination under the Equal Protection clause."78 What is of interest here, though, is that this requirement of purpose is important to Equal Protection doctrine (at least where there is no express classification that receives strict scrutiny for that reason) and it has been for several decades.

\section{Discriminatory Intent and Voting Rights}

In the voting rights context, regarding Fourteenth and Fifteenth Amendment legislation, the Supreme Court noted in City of Richmond, that "gross racial slurs" intended to single out black citizens, can be forbidden and have "no legitimacy at all under our Constitution."79 Or, in 1970 is Gomillion v. Lightfoot, the Court held that a redistricting effort that excluded almost all of the black residents of Tuskegee Alabama was unconstitutional where acts "generally lawful may become unlawful when done to accomplish an unlawful end." ${ }^{0}$ In contrast, the Justices tend to defer to districting when states base

\footnotetext{
75515 U.S. 900, 915 (1995).

76413 US 528, 533 (1973). In general, absent strict or intermediate scrutiny, a classification challenged must be "rationally related to a legitimate state interest." New Orleans $v$. Dukes, 427 U.S. 297, 303 (1976).

77 Reva Siegel, Why Equal Protection No Longer Protects: The Evolving Forms of StatusEnforcing State Action, 49 STAN. L. REV. 1111 (1997).

78 David Baldus et al, 263, in Death Penalty Stories, Carol and Jordan Steiker, eds. (2009).

${ }^{79}$ City of Richmond, 422 U.S. 358, 378-79 (1975).

80364 U.S. 339, 347 (1960).
} 


\section{UNCONSTITUTIONALLY ILLEGITIMATE DISCRIMINATION}

decisions on "legitimate considerations." 11 In the voting context as well, the Justices have explained that it is not easy to define or prove what consists in "discriminatory purpose," and that this "evidentiary difficulty," along with the "the sensitive nature of redistricting and the presumption of good faith that must be accorded legislative enactments," requires judges to "exercise extraordinary caution" when reviewing claims of race discrimination in districting. ${ }^{82}$ That said, while it is hard to put to one side those practical obstacles that the doctrine places in the way of relief for plaintiffs, the Court has also expressed in voting rights cases the reason why discriminatory purpose matters in that context. The Court has emphasized that discrimination has larger effects beyond harming minority voters. It may "balkanize us into competing racial factions" and this can "cause society serious harm." 83 That larger social harm is the focus of the analysis here: the effect on legitimacy of government.

\section{Discriminatory Intent and the Sixth Amendment}

In jury selection and deliberation cases concerning the Sixth Amendment, the Supreme Court's cases have been quite clear that regardless how one measures the harm (and it is hard to quantify it), the institutional cost of racial bias infecting criminal trials is great. That context provides a useful example for the principles discussed in this Article. In that context, after all, the intent expressed by a juror is irrelevant to a theory of financial harm. The juror is not being sued for damages. The defendant is seeking to overturn a conviction, and the question is whether the intent of a juror tainted an entire trial. The Sixth Amendment focus is on the systematic repercussions of an expression of discriminatory intent. ${ }^{84}$ Thus, in the last term in Pena-Rodriguez v. Colorado, the Court emphasized:

The duty to confront racial animus in the justice system is not the legislature's alone. Time and again, this Court has been called upon to enforce the Constitution's guarantee against state-sponsored racial discrimination in the jury system. ${ }^{85}$

The Court held that if a juror makes a "clear statement" that indicates reliance on "racial stereotypes or animus" then the trial court must consider whether there is a Sixth Amendment violation in that case. ${ }^{86}$ The Court

\footnotetext{
81 Reynolds, 377 U.S., at 579.

82 Miller v. Johnson, 515 U.S. 900, 916 (1995).

${ }^{83}$ Id. at 912 (quoting Shaw v. Reno, 509 U.S. 630, 657 (1993)).

84 This was not always so, and for a description of the change in the Supreme Court's jurisprudence regarding peremptory challenges, see Barry Friedman, Habeas and Hubris, 45 VAND. L. REV. 797-98 (1992).

85 Pena-Rodriguez v. Colorado, 137 S.Ct. 855, 867 (2017).

86 Id. at 869.
} 


\section{UNCONSTITUTIONALLY ILLEGITIMATE DISCRIMINATION}

emphasized that "[n]ot every offhand comment indicating racial bias or hostility will justify" such an inquiry. Instead, the court must find that statements must show that racial animus was "a significant motivating factor" in the juror's vote. ${ }^{87}$ Again, the discussion of the larger impact of racial bias during jury trials is the focus here. The Court highlighted that larger harm, where: "Permitting racial prejudice in the jury system damages both the fact and the perception of the jury's role as a vital check against the wrongful exercise of power by the State." 88 Thus, the Court highlighted, citing its 1979 ruling in Rose $v$. Mitchell, that race discrimination, while "odious in all aspects, is especially pernicious in the administration of justice." 89

But a remedy is not important because of the need to ensure fairness to the particular defendant. Rather, the Court emphasized that the "fact and the perception" of the jury's unbiased role is critical to the legitimacy of the criminal justice system as a whole, the Justice emphasized. ${ }^{90}$ That reasoning is very much aligned with the argument highlighted here: imposing serious remedies for intentional discrimination, such as doing over an entire criminal trial, is needed to safeguard the legitimacy of the entire system.

\section{Dormant Commerce Clause and Purpose}

The Supreme Court's doctrine in the Dormant Commerce Clause setting has also increasingly emphasized a purpose-based view that an intent to engage in protectionism and favor local commerce violates the Clause. ${ }^{91}$ Regulation of commerce is acceptable if it is based on "legitimate" regulatory considerations and there are not reasonable non-discriminatory means to carry out those goals. ${ }^{92}$ As in other areas, the courts may not be able to define the array of legitimate regulatory actions that government can take. The Court bars facial discrimination, where a local measure distinguishes between local and interstate commerce in its text, as well as regulation that is "clearly excessive" in its burden on non-local commerce, under the Pike test. 93 Increasingly, the Court has emphasized intent to discriminate, or "protectionist animus." 94 The Court has declined to strike down regulations

$87 \mathrm{Id}$.

88 Id. at 868 (citing Powers v. Ohio, 499 U.S. 400, 411 (1991).

89 Id. (quoting Rose v. Mitchell, 443 U.S. 545, 555, (1979)).

$90 \mathrm{Id}$.

${ }^{91}$ Daniel Francis, The Decline of the Dormant Commerce Clause, 94 Denv. L. REV. 255 (2017).

92 Dep't of Revenue v. Davis, 553 U.S. 328, 338-39 (2008) (plurality opinion).

93 Wyoming v. Oklahoma, 502 U.S. 437, 455-56 (1992); Pike v. Bruce Church, Inc., 397 U.S. 137 (1970).

${ }^{94}$ Francis, supra, at 280. For an early and influential call for the courts to focus on purposeful discrimination, see Donald H. Regan, The Supreme Court and State Protectionism: Making Sense of the Dormant Commerce Clause, 84 MICH. L. REV. 1091 (1986). 


\section{UNCONSTITUTIONALLY ILLEGITIMATE DISCRIMINATION}

for which there was "no discriminatory intent," ${ }^{55}$ or strike down legislation where the "avowed purpose" and the "motive behind it" is protectionism. ${ }^{96}$ The caselaw is complex and has been criticized for sometimes inferring purpose from effect and sometimes not finding a protectionist purpose when a law favors local government on its face. ${ }^{97}$ Whether the doctrine is consistent or principled or sound is not my focus here; what is relevant is that the Court deems as a central constitutional evil intentional or purposeful discrimination by government, so much so that expression of it can disable government policymaking.

\section{Bad Faith Executive Action}

Cases regarding structural powers also reflect the concern with the legitimacy of government action. In a set of cases regarding whether the Executive acted within the scope of the immigration power, or rather violated the due process or other constitutional rights of a person, the Court has asked whether the Government has a "facially legitimate and bona fide" reason for denying entry to the United States. In so doing, the Court has examined whether the Government acted in "bad faith," or with intent to unconstitutionally discriminate. ${ }^{98}$ If so, the Executive would arguably be acting outside of the discretion conveyed by the immigration power. That illegitimate action may raise constitutional questions regarding the structural powers of government, is an argument that has not been sufficiently been developed in the caselaw and the constitutional law literature, and I develop it further in Part II.

\section{The Harm and the Cost of Discriminatory Intent}

As these constitutional doctrines convey, cost of discriminatory intent is not simply the harm to a plaintiff in a case. Often the Justices recognize that the cost is broader and more structural than the harm to victims: it affects the reputation and legitimacy of government itself. It may affect the perception that government is neutral with respect to religion, or that government is race-neutral in criminal trials, or that government is not discriminating in favor of local government. The harm to individuals may be real and substantial, but the cost to the legitimacy of government is far greater than is often acknowledged in the literature.

\footnotetext{
95 Bacchus Imports v. Dias, 468 U.S. 263, 272-73 (1984).

96 W. Lynn Creamery v. Healy, 512 U.S. 186, 194, 196 (1994).

97 Francis, supra, at 286-87, 292 ("Under the Rehnquist and Roberts Courts, in cases without evidence of a subjective intention to distort competition, the rule against discrimination has collapsed.").

98 Kerry v. Din, 135 S. Ct. 2128, 2139-41 (2015) (Kennedy, J., concurring in the judgment); Fiallo v. Bell, 430 U.S. 787 (1977).
} 


\section{UNCONSTITUTIONALLY ILLEGITIMATE DISCRIMINATION}

Jeremy Waldron has developed this point in his book "The Harm in Hate Speech," describing just how broad the cost can be in the context of hate speech, not by government, but by private individuals as well. While Waldron's argument does not necessarily implicate government legitimacy (and the concerns are far greater when it is the government itself that is engaging in what Waldron calls hate speech), Waldron sets out that a society that tolerates derogatory speech towards victims not only permits harm to victims, but also undermines the dignity and legitimacy of that society. ${ }^{99}$ Waldron argues that a plural democracy has as a central public good that society is "for" everyone, and that members of all groups know that they will not face "hostility, violence, discrimination, or exclusion by others." 100 Speech that undermines that good creates a "slow-acting poison," that undermines society. ${ }^{101}$ In turn, it creates more than just a harm to particular individuals who receive directly the hate speech, but it harms "basic social standing" as group members more broadly, which Waldron terms "dignity."102 Added to Waldron's concerns, where the government is the speaker, is the concern with the legitimacy of government itself. To have the government itself making statements that encourage "hostility, violence, discrimination, or exclusion" creates yet another order of harm to the entire polity.

Reva Siegel has described in the equal protection context, how in recent cases, a group of the Justice has been concerned with what she aptly terms the "balkanization" concern: a concern not just with racial classifications or subordinating minority groups, but rather the "social divisiveness" that would result from certain race-conscious remedies or practices. ${ }^{103}$ The anti-subordination principle in equal protection law focuses on harms that disproportionately affect members of marginalized groups. As Siegel develops, some Justices are not comfortable remedying those harms, but nor with focusing more formally in a "colorblindness" approach only on whether race is used as a classification. Instead, they ask whether government practices would tend to "anticipate and endeavor to ameliorate race-conscious resentments." 104 Such a view could adopt a sociological legitimacy approach and empirically examine whether inter-group friction results from a government practice. Instead, the Justices make their own judgments about what practices seem likely to aggravate tension. They are attentive to the "appearance" that government action takes and what consequences can flow from that. ${ }^{105}$ Thus, Siegel describes how in Parents

\footnotetext{
99 Jeremy Waldron, The Harm in Hate Speech (2012).

100 Id. at 4.

$101 \mathrm{Id}$.

$102 \mathrm{Id}$. at 5.

103 Reva B. Siegel, From Colorblindness to Antibalkanization: An Emerging Group of Decision in Race Quality Cases, 120 YALE L. J. 1278 (2011).

104 Id. at 1300.

105 Id. at 1300.
} 


\section{UNCONSTITUTIONALLY ILLEGITIMATE DISCRIMINATION}

Involved, Justice Anthony Kennedy described how race-reassignment plans in public schools, if handled without care, "can lead to corrosive discourse, where race serves not as an element of our diverse heritage but instead as a bargaining chip in the political process."106

Such rulings reflect a concern with social divisiveness that extends beyond situations in which there is a showing of unconstitutional intent. However, the balkanization approach in such cases, that Siegel importantly brings out, helps us to understand the caselaw and the focus on the broad legitimacy-based consequences of discrimination discussed here. That some Justices are more broadly concerned with the problem of divisiveness helps to explain why they may be particularly concerned with it when intent to be divisive is manifest. The problem with balkanization, as well, can be explained as a problem of moral legitimacy, and a cost felt across society. The concern that Siegel raises is that the concern with the cost of divisiveness extends to all of society, including non-minority groups, and it can minimize remedies for harm directed to minority groups. There can be tension between the legitimacy-focused approach, advanced here, and an anti-subordination focus. For these purposes, I just want to underscore that each of the types of harms, to the individual, to the group, to society, and then the cost to moral legitimacy of government, are broad and important. It is the latter, the cost to legitimacy, however, that is not clearly set out in constitutional doctrine or in the scholarship explaining why discriminatory intent matters.

\section{Defining Intent}

Rather than take on the systematic scope of those harms to the individual, group, society, and then the cost to government, scholars have tended to focus more narrowly on constitutional doctrine as set out by the Supreme Court. In response to the caselaw just described, some scholars have also taken the various ways in which intent can be constitutionally impermissible to mean that the doctrine is inconsistent. After all, the Supreme Court adopts different formulations of what suffices to prove intent, and even different notions of what consists in intent. Richard Fallon has argued that the doctrine is in some disarray in a recent article that carefully canvases doctrines regarding legislative intent across a range of constitutional contexts. ${ }^{107} \mathrm{My}$ focus is not on how intent is defined or proved; my focus is on moral legitimacy and not on the legal legitimacy of existing doctrine. However, the doctrine is more coherent, I will argue, than some maintain, if one turns from those difficult evidentiary questions. Different words are used by the Court to express standards in different areas. While putting to one side what level of proof or what definition of intent courts do or

\footnotetext{
106 Id. at 1307 (quoting Parents Involved, 551 U.S. at 797).
}

107 Fallon, supra note xxx. 


\section{UNCONSTITUTIONALLY ILLEGITIMATE DISCRIMINATION}

should adopt, I argue that the fundamental underlying problem of cost to legitimacy remain quite similar across a range of constitutional doctrines.

To expand on the argument that evidentiary problems make discriminatory intent doctrines poor sources for doctrine, Richard Fallon has recently argued that "some conceptions of forbidden legislative intent purport to be objective, not subjective, due to their exclusive focus on publicly observable conditions--such as statutes' facial discrimination against racial or religious minorities." 108 Such objective conceptions are suitable, but Fallon argues that since they focus "solely on statutes' facial content or publicly measurable effects" then the reference to intent "does no real analytical work." ${ }^{109}$ As described, the Court does not always (or even typically) refer to actual intent, in the subjective sense, of lawmakers. Fallon argues that "we should reconceptualize doctrines that ascribe forbidden intentions exclusively on the basis of specified statutory content or effects as substantive doctrines that prescribe results directly on the basis of that content or those effects." 110 In my view, that is what we largely already have in the doctrine. Specifically, the breed of content prescribed are illegitimate actions based on discrimination. When the government acts with the purpose or intent to discriminate, it is acting in a substantively unauthorized way.

The terminology used to express a constitutional intent claim may get in the way and explain the seeming use of subjective and not objective criteria for ascertaining intent. For example, animus is the term that many constitutional litigators and scholars use to label claims that forbidden intent motivated government actors, although in other contexts the term used is "purpose" and in others, "intent." Take for example, an amicus brief of constitutional law scholars in the litigation surrounding the immigrationrelated Executive Orders issued in 2017. Amici argue: "The extraordinary record in this case demonstrates that President Trump's principal motive in issuing the Order was anti-Islamic animus."111 Those scholars are speaking of an order "not explicitly denominated a "Muslim Ban," but which had the effect of doing so as its "true purpose," they argued, based on the President's "animus-laded campaign promise," and not for "any constitutionally legitimate reason."

Those arguments have a great deal packed into them. On one level, it is odd that they would use the term "animus," when animus has often been used to refer to claim in which there is only rational basis review under the Equal Protection Clause. If there is strict scrutiny, because a suspect characteristic (like race or like religion) is implicated, then the doctrine

\footnotetext{
108 Fallon, supra note xxx, at 529.

109 Id. at 529.

$110 \mathrm{Id}$. at 529 .

111 Motion for Leave to File Amicus Brief in Three Related Proceedings and Brief of Constitutional Law Scholars as Amici Curiae Opposing the Government's Application for Stay, Trump v. Hawaii, 2017 WL 2591417 ( Nos. 16-1436, 16A1190, 16A1191, June 13, 2017).
} 


\section{UNCONSTITUTIONALLY ILLEGITIMATE DISCRIMINATION}

supports using the term "purpose" or "intent." However, the claims in that case relate to both the First and Fourteenth Amendments. In the First Amendment Establishment Clause context, the Justices have forbidden the government from acting with "animus" towards any particular religion. ${ }^{112}$ The Court has said that it is wrong for the government to "signal disfavor" towards a religious group or to "denigrate" a religious group. ${ }^{113}$

Purpose, rather than the word animus, is the concept typically used in Establishment Clause cases. The Court has described the central concern as "an official purpose to disapprove of a particular religion or of religion in general," 114 or under the Lemon test, conversely described as the Government's burden to show that an action has "a secular legislative purpose." 115 Just as purpose or intent is the overarching concept used in the Equal Protection Clause cases, purpose is emphasized in the First Amendment context. Animus may be a way of sometimes characterizing government intent, ${ }^{116}$ but it is not the way the Court typically refers to the overarching standard.

Returning to the Equal Protection Clause, even in the types of cases that animus is particularly used to refer to, rational basis cases that nevertheless result in relief for plaintiffs, the Court does not often use the term "animus" to explain the result. In the seminal cases in that line of cases that are sometimes referred to in shorthand as animus cases, in United States Department of Agriculture $v$ Moreno, the Court put it this way:

For if the constitutional conception of 'equal protection of the laws' means anything, it must at the very least mean that a bare congressional desire to harm a politically unpopular group cannot constitute a legitimate governmental interest. ${ }^{117}$

Relying on the same language, in City of Cleburne $v$ Cleburne Living Center, the Justices reiterated that "some objectives--such as 'a bare ... desire to harm a politically unpopular group'-- are not legitimate state interests." 118 A

112 See, e.g., Town of Greece v. Galloway, 134 S. Ct. 1811, 1822 (2014); id. at 1831 (Alito, J., concurring); Bd. of Educ. of Kiryas Joel Vill. Sch. Dist. v. Grumet, 512 U.S. 687, 722, 728 (1994) (Kennedy, J., concurring in the judgment); Larson v. Valente, 456 U.S. 228, 244 (1982); see also Church of the Lukumi Babalu Aye, Inc. v. City of Hialeah, 508 U.S. 520, 532 (1993).

113 Town of Greece, 134 S.Ct. at 1824, 1826.

114 See Church of the Lukumi Babalu Aye, Inc. v. City of Hialeah, 508 U.S. 520, 532 (1993).

115 Lemon, 403 U.S. at 612-13 (quoting Walz v. Tax Comm'n of the City of New York, 397 U.S. 664, 674 (1970)).

116 Hernandez v. Comm'r of Internal Revenue, 490 U.S. 680, 696 (1989) (finding challenged law survived Lemon test's purpose prong where "there is no allegation that [it] was born of animus").

117413 US 528, 533 (1973).

118473 US 432 (1985). 


\section{UNCONSTITUTIONALLY ILLEGITIMATE DISCRIMINATION}

case that does use the term "animus" is Romer v. Evans. In Romer, the Court explained that "imposing a broad and undifferentiated disability on a single named group" was "inexplicable by anything but animus toward the class it affects." 119

Thus, the definition of animus or intent or purpose is important, but it often does not explain the reasoning or results of decisions. Often discriminatory intent is largely proved by the absence of what may matter more: a legitimate basis for government decisionmaking. Take for example, recent rulings in which the Court has not relied on the term "animus" (and for good reason, I argue here). In Windsor, the Court explained that "a bare congressional desire to harm a politically unpopular group cannot' justify disparate treatment of that group." 120 This was an intentional choice. Justice Kennedy was referring to language in cases like Moreno in which lawmakers targeted a group with little or no justification, raising the concern that they were intentionally trying to harm the group. The focus is as much on the legitimacy of the government action as on the "intent" of the lawmakers. In other more recent opinions, Justice Kennedy has stepped away from any implication that animus involves an intentional and conscious hatred of the target group. Justice Kennedy has written:

"Prejudice, we are beginning to understand, rises not from malice or hostile animus alone. It may result as well from insensitivity caused by simple want of careful, rational reflection or from some instinctive mechanism to guard against people who appear to be different in some respects from ourselves." 121

Justice Kennedy's ruling in Obergefell $v$. Hodges similarly emphasized that denial to same-sex couples of the right to marry expressed "disapproval of their relationships" and "serves to disrespect and subordinate them." 122 That ruling employs a public reason approach in that it emphasizes that one group was not treating fellow citizens as equals with regard to marriage. ${ }^{123}$

Similarly, in religious discrimination cases, the Court has acknowledged that officials might not "understand" or "failed to perceive" the

\footnotetext{
119 Romer v Evans, 517 US 620, 632 (1996).

120 United States v Windsor, 133 S Ct 2675, 2694 (2013)

121 Bd. of Trustees of Univ. of Ala. v. Garrett,531 U.S. 356, 374 (2001) (Kennedy, J., concurring).

122135 S.Ct. 2584, 2604 (2015). For discussion of the role of public reason in the decision, see, e.g. Robert Katz, The Role of Public Reason in Obergefell v. Hodges, 11 FIU L. REV. 177 (2015).

${ }^{123}$ For a discussion of the language on Obergefell that disparages non-marital relationships and is therefore inconsistent with the public reason approach in the opinion, see Gregg Strauss, Valorizing Marriage (draft on file with author). See also Melissa Murray, Obergefell v. Hodges and the New Marriage Inequality, 104 Calif. L. Rev. 1207, 1249 (2016).
} 


\section{UNCONSTITUTIONALLY ILLEGITIMATE DISCRIMINATION}

bias. ${ }^{124}$ Or the Justices have discussed the harm arising from "unconscious prejudices and disguised animus," as well as the social harms of "covert and illicit stereotyping." 125

The term animus could be taken to imply action or words dripping with hatred. However, as the discussion above suggests, the term does not mean that actors possessed subjective motivation, necessarily, as it is used in cases. "Animus" can refer to situations in which the justifications for targeting a group are extremely weak and there is no overt evidence of subjective intent to harm a group. Instead, the desire to harm is inferred from the circumstances and the nature of the government act. The precise role that animus plays, as opposed to a claim that discrimination is purposeful, is still unclear in the doctrine. Dale Carpenter writes that "the constitutional anti-animus principle remains an unappreciated one. There is little consensus about what animus is; about whether, why, and when it is constitutionally problematic; or about what the appropriate role of courts, if any, should be in policing it." 126 One reason that the role animus plays is less clear is that it is used in cases in which intent of government actors plays a role, but the scrutiny is not strict. ${ }^{127}$ Animus, or intentional discrimination, plays a role in the result in such cases, but so does the government's lack of justification for its action against a group. As discussed in the next Part, the more general relationship between the intent evidence and the government's justifications, or lack thereof, is a better place to look to explain the doctrine.

\section{E. From Harm to Cost}

I have argued that the focus of discriminatory intent doctrine should not be on the harm to victims. Such harm can be great and it should not be trivialized, but even if such harm is hard to identify, the problem remains great. Instead, I argue, the focus should be on the larger cost to society. That cost is systematic and it is structural. Government discrimination does not just create divisiveness that impacts society broadly, as in a balkanization theory, but also impacting the legitimacy of government itself. In the areas

${ }^{124}$ Lukumi, 508 U.S. at 524.

125 Texas Dep't of Hous. \& Cmty. Affairs v. Inclusive Communities Project, Inc., 135 S. Ct. 2507, 2522 (2015).

126 Dale Carpenter, Windsor Products: Equal Protection From Animus, 2013 Sup. Ct. Rev. 183 (2013).

127 Susannah W. Pollvogt, Unconstitutional Animus, 81 FordHAM L REV. 887 (2012); William N. Eskridge, Jr., Some Effects of Identity-Based Social Movements of Constitutional Law in the Twentieth Century, 100 Mich L Rev 2062 (2002); Elizabeth S. Anderson and Richard H. Pildes, Expressive Theories of Law: A General Restatement, 148 U. PA. L. REV. 1503 (2000); Barbara J. Flagg, "Animus" and Moral Disapproval: A Comment on Romer v. Evans, 82 Minn. L. REv. 833 (1998); Ashutosh Bhagwat, Purpose Scrutiny in Constitutional Analysis, 85 Cal L Rev 297 (1997); Kenji Yoshino, The New Equal Protection, 124 HARV. L REV. 747 (2011). 


\section{UNCONSTITUTIONALLY ILLEGITIMATE DISCRIMINATION}

of caselaw described above, the Court often acknowledges the severity and the scope of the cost. Thus, having a racist juror sitting in a criminal trial does not just implicate a single criminal conviction, but it calls into question the legitimacy of the criminal justice system. Religious discrimination does not just harm believers, but it comes at a cost to the state's neutrality in general on religious matters.

It must also be emphasized that even more narrowly drafted judicial rulings can have more sweeping implications on closer examination. In Lawrence v. Texas, Justice Sandra Day O'Connor stated, "moral disapproval of a group cannot be a legitimate government interest," and then explained the wide range of legal consequences that criminal sodomy laws imposed.128 Even if the laws were rarely enforced, they did more than just state moral disapproval, as serious as that was, but the laws resulted in "discrimination against homosexuals as a class in an array of areas outside the criminal law." 129 The law permitted a case system in which an entire group faced systematic legal disadvantages, in addition to the moral condemnation implied by the law. Those broad and systemic consequences, both legal and social, of discrimination, explain why it is taken so seriously in constitutional doctrine, but they also explain why narrower theories of the harm of discrimination do not fully capture the degree of the problem.

In some areas, however, the Supreme Court has required a showing that "purposeful discrimination had a discriminatory effect" on a particular plaintiff. ${ }^{130}$ In stating that, in the case of McCleskey $v$. Kemp, the Justices explained that to show this, the defendant would have to show that there was discrimination in his criminal case. ${ }^{131}$ That requirement is not consistent with the type of harm that purposeful discrimination, if shown, would cause. The Court, in fact, often permits relief based on racial classifications or group-based discrimination even if one cannot show that one's case was definitely affected; the Sixth Amendment cases just discussed in which a juror was affected by racial bias, but one cannot say to what degree it impacted the decision to convict, are an example in the criminal law setting. The concept of discriminatory intent as one that impact legitimacy of government, broadly, should call into question doctrines requiring heightened standing or causation for a plaintiff to bring a case. That language in McCleskey is inconsistent with what the Court required in cases before and since, but it is also deeply inconsistent, I would argue, with the deeper purpose of having intent tests.

A different theory of discriminatory intent's role in the doctrine is that such expressions themselves harm individuals and should be forbidden for that reason. That view of equal protection law, and constitutional harm more

\footnotetext{
${ }^{128}$ Lawrence v. Texas, 539 U.S. 558, 581 2003) (O’Connor, concurring).

$129 \mathrm{Id}$. at 584 .

130 McCleskey v. Kemp, 481 U.S. 279, 292 (1987).

$131 \mathrm{Id}$.
} 


\section{UNCONSTITUTIONALLY ILLEGITIMATE DISCRIMINATION}

generally, supports the concept that judges should attend to statements made by government actors and the messages sent by government acts. Such an expressive theory in a sense would address the concern that the Court in a ruling like McCleskey conceives of the harm of race discrimination too narrowly. However, expressive harm theories in their own way narrow the focus to the harm that such statements cause to victims. Thus, in Establishment Clause cases, Court has suggested: "Endorsement sends a message to nonadherents that they are outsiders, not full members of the political community, and an accompanying message to adherents that they are insiders, favored members of the political community. Disapproval sends the opposite message." 132 In voting discrimination cases, the Justices have described the harms as "expressive harms." 133 Such statements in the doctrine support the notion that expressive harm matters in constitutional law. Constitutional theorists argue that expressive harm should in fact be a focus of certain constitutional inquiries. ${ }^{134}$

In this Article, I argue that while valuable, theories of expressive harm as insufficient to fully capture the full cost of discrimination. Indeed, antisubordination theories focusing more broadly on harm to minority groups, do not share quite as wide a lens as this legitimacy approach. Instead, my focus is not on harm, but the cost to legitimacy of government. A different view of the expressive dimension of discrimination, not focused on harm, has been developed by Deborah Hellman. ${ }^{135}$ On Hellman's view, a law or policy can be assessed and may constitute unconstitutional discrimination based on message conveyed or its meaning rather than based on expressive or other harm. That view is highly compatible with the legitimacy-focused approach I develop here.

To be sure, the lines can blur between expressive harm to the affected individuals, and then the group, then extending to society, and then the cost in legitimacy to government. Some of the statements above that support an expressive harm theory also support the concern that sending a message of disparagement is something that the government should not do. Justice Kennedy referred to the "danger of stigma and stirred animosities," if

\footnotetext{
132 Lynch, 465 U.S. at 687, 688 (O'Connor, J., concurring).

133 Bush v. Vera, 517 U.S. 952, 984 (1996); id. at 1053 (Souter, J., dissenting); see also Richard H. Pildes \& Richard G. Niemi, Expressive Harms, "Bizarre Districts," and Voting Rights: Evaluating Election-District Appearances after Shaw v. Reno, 92 MicH. L. REv. 483, 483-84 (1993).

134 See Pildes \& Niemi, supra; see also Fallon, supra note xxx, at 530 ( "In some instances, the publicly identified, forbidden subjective intentions of less than a majority of the legislature may help to give a challenged statute an objective "expressive" effect that stigmatizes a racial or religious minority or promotes religion to a greater than de minimis extent.").

${ }^{135}$ Deborah Hellman, The Expressive Dimension of Equal Protection, 85 U. Minn. L. Rev. 1 (2000).
} 


\section{UNCONSTITUTIONALLY ILLEGITIMATE DISCRIMINATION}

religious line-drawing occurs. ${ }^{136}$ There, the focus extends beyond the target group to all affected by the inter-religious harm that results. Such broadly conceived harms can be viewed as societal. The line between a harm to everyone in society and a cost that also undermines the legitimacy of government can be fine indeed. It may make sense for judges not to bother trying to draw such fine lines. Harms that extend so broadly as create a cost to much of society will also damage government legitimacy so greatly that the constitutional problem deserves a substantial remedy whether due to harm to victims, or the cost to government legitimacy, or both.

\section{ThE EFFECTS OF DisCRIMINATORY INTENT ON LEGITIMACY}

In Part I, I have argued that the harm of discriminatory intent should not be the focus. Instead, the focus should be on the larger costs, where discrimination affects the very structure and moral legitimacy of government. I have argued that a rule that explicitly focuses on the legitimacy of government action both explains much of current doctrine and can improve upon it. Such a rule makes clearer what work claims of unconstitutional intent do and what the stakes are.

Take one possible and often-advanced explanation of why intent matters: that it provides evidence that what the government is really doing is in fact discriminatory. However, if the goal is to assess what consists in discrimination, other tools in addition to intent might serve that goal equally well. For example, if the goal is to remedy disparate outcomes, then there would be no need to rely on intent as a proxy. One could focus primarily on the disparate outcomes themselves. On a theory of sociological legitimacy, perhaps that would sensibly be the focus. From that perspective, scholars have criticized intent doctrine as misleading and not asking the right questions or permitting the right remedies. I agree and I have often argued that such an empirical perspective is highly valuable in constitutional law generally. However, one place it which it does not capture the appropriate harm is in this area of disparagement and discriminatory intent, where the harm to moral legitimacy is extremely hard to quantify and measure.

Many have criticized intent doctrines generally, where "it is altogether possible for a law which is the expression of a bad motive to be a good law."137 Or, as John Hart Ely has put it, the Constitution should not be "an instrument for punishing the evil thoughts of members of the political branches by knocking down handiwork of theirs which under other circumstances would count as legitimate."138 Ely suggested it would be even worse to reframe the inquiry into motivation as one into "purpose," which is

\footnotetext{
136 Kiryas Joel, 512 U.S. at 728 (Kennedy, J., concurring in the judgment)

137 Jospeh Tussman \& Jacobus tenBroek, The Equal Protection of the Laws, $37 \mathrm{CA} . \mathrm{L}$. REV. 341, 360 (1949).

138 Ely, Motivation, supra note xxx at 1216.
} 


\section{UNCONSTITUTIONALLY ILLEGITIMATE DISCRIMINATION}

precisely how the Supreme Court proceeded to reframe the inquiry in a series of constitutional contexts. ${ }^{139}$ However, Ely concluded that legislation is not legitimate if its motivation is to disadvantage minority groups. ${ }^{140}$ Why might that be, even if one is skeptical of relying on intent or purpose in constitutional doctrine generally? In the end, Ely seems comfortable with intent doctrines if limited to areas in which disadvantaged minority groups are the target of government action that harms them.

A second explanation for why one would have intent doctrines is that intent itself constitutes a harm that has the effect of denigrating targeted individuals. Such expressive harms, or subordinating messages, could themselves be the problem. As discussed in Part I.D, I reject that view as too narrow and insufficient to capture the full harm of discriminatory intent.

A third explanation is that for the government to openly rely on discriminatory criteria in its decisionmaking has a structural cost. Such action makes government actors less worthy of trust and illegitimate. That third explanation is the one that I focus on in this Article.

In this Part, I focus on the effects of a showing of discriminatory intent and the costs and benefits to government. First, I develop how evidence discriminatory intent can undermine government defenses to a constitutional claim. Second, I develop how a legitimacy-based approach towards discriminatory intent incentivizes neutral and non-discriminatory government action. Third, I argue that evidence of ill intent can help with an argument that the government has exceeded the bounds of its structural power to act. Illegitimacy can thus taint the government and affect its ability to act or defend its actions. It does not always have the structure of a plaintiff trying to "prove" intent. Some acts are so corrosive that they may undermine the government's ability to act. Those consequences will be further developed in Part III.

\section{A. Undermining Government Defenses}

In each of the constitutional contexts discussed, evidence of bad purpose, intent or faith can serve not just to buttress a claim of discrimination, but also to undermine government defenses to a constitutional claim. Thus, it need not be just an element of expressive harm that plaintiffs suffer and it does not necessarily just define the plaintiff's required showing of purpose or intent. Instead, evidence of intent (sometimes including evidence of a prima facie case or evidence of disparate impact) can sometimes shift the burden to the Government to explain itself. This is the standard approach for statutory discrimination claims under Title VII.

The focus here is not on evidentiary burdens for assessing claims of discrimination, but rather the purpose of forcing the Government to do more

139 Id. at 1218.

140 Id. at 1224-25. 


\section{UNCONSTITUTIONALLY ILLEGITIMATE DISCRIMINATION}

if there is evidence of intentional discrimination. That purpose is not just evidentiary. There is a different goal: to repair the legitimacy of Government that is damaged by expressed intentional discrimination. It is itself a good thing to incentivize government actors to adopt neutral and non-group-based reasons for their actions. If it is a burden of government to show that its actions are legitimate and not based on corrosive desire to harm groups, whether defined objectively or subjectively or both, then the structure of the claim itself gives the government a chance to redeem its legitimacy. That also helps to explain why in so many areas, the doctrine involves objective and not just subjective analysis. The Government may simply seek to counter that officials acted with subjective discriminatory intent, but in offering a neutral ground for its action and evidence to support that neutral ground, the Government may commonly rely upon objective evidence, such as statements made in support of the action, the practical effects of the action, the pattern of its enforcement, and its likely beneficiaries.

The Establishment Clause context provides a good illustration of this in operation, perhaps in part because the focus has long been not just on the preference given to a religious group but on the cost to Government to be playing any role in matters of religion at all. Thus, in the Establishment Clause context, the Court has said that in examining whether the "primary purpose" of an act is secular, the approach seeks to ascertain the "official objective . . . from readily discoverable fact, without any judicial psychoanalysis of a drafter's heart of hearts."141 The Court is an "objective observer." 142 The approach analyzes "external signs" such as "text, legislative history, and implementation" of the official act. ${ }^{143}$ The "specific sequence of events" leading to the official action is considered. ${ }^{144}$ Nor is such an inquiry limited to just the final decisionmakers in a government process. ${ }^{145}$ The Supreme Court has explained that: "[w]hen there is [] proof that a discriminatory purpose has been a motivating factor in the decision," a court may consider "contemporary statements by members of the decisionmaking body." 146 In so doing, courts often find no evidence of discriminatory purpose. In its Town of Greece ruling, the Court held that "[i]n no instance did town

\footnotetext{
141 McCreary, 545 U.S. at 862.

$142 \mathrm{Id}$.

$143 \mathrm{Id}$.

144 Edwards, 482 U.S. at 595.

145 See, e.g. Standard v. A.B.E.L. Servs., Inc., 161 F.3d 1318, 1330 (11th Cir. 1998) (" $[\mathrm{R}]$ emarks by non-decisionmakers or remarks unrelated to the decisionmaking process itself are not direct evidence of discrimination. . . But when those statements reveal something about the government's purpose, they are certainly part of the evidence we review for purpose."); see also Fourth Circuit ruling ("The distinction between candidate and elected official is thus an artificial one where the inquiry is only whether the reasonable observer would understand the candidate's statements to explain the purpose of his actions once elected.”).

146 Village of Arlington Heights v. Metro. Hous. Dev. Corp., 429 U.S. 252, 266-68 (1977).
} 


\section{UNCONSTITUTIONALLY ILLEGITIMATE DISCRIMINATION}

leaders signal disfavor toward nonparticipants or suggest that their stature in the community was in any way diminished." 147 That interpretation of the town's legislative prayer policy is not uncontroversial, and higher-courts may not always be best situated to assess a factual record to make these determinations.

To take another prominent and recent example of a legitimacy-based approach, consider the ruling of the Supreme Court in United States $v$. Windsor. There the Court held that "no legitimate purpose overcomes the purpose and effect to disparage and to injure those whom the State, by its marriage laws, sought to protect in personhood and dignity." 148 That ruling nicely brings to the fore a sharp debate over whether this approach is the right one. In dissent, Justice Antonin Scalia agreed, except as to the evidence demanded. "Laying such a charge against them," he declared, "should require the most extraordinary evidence." 149 Yet "extraordinary evidence" has never been required in such cases; if expressed intent to discriminate is seriously harmful to government and is of grave concern, one may not shy away from taking action based on good evidence of such intent, rather than "extraordinary" evidence. What is highly relevant about the interchange in Windsor, though, is that the focus is on the speaker, what must be shown about that speaker, and not on the degree of harm to the victims.

The Supreme Court's ruling in United States v. Windsor has puzzled some commentators who, like Justice Scalia and Chief Justice Roberts in their dissents, were skeptical that the plaintiffs had sufficient evidence for the claim that the Defense of Marriage Act lacked any "legitimate purpose overcomes the purpose and effect to disparage and to injure."150 Prof. Brian Soucek, for example, asks why the majority "needed to place so much emphasis on animus" in its opinion, if the DOMA served no legitimate federal interests. ${ }^{151}$ I view Windsor differently. For the majority, the question was whether Congress had intended to limit state marriage regulation, and not whether the intent was to harm same-sex couples. As a result, the Court relied on "strong evidence" that "the congressional purpose [was] to influence or interfere with state sovereign choices about who may be married." 152 The Court emphasized the "history of DOMA's enactment and its own text," in its analysis, including statements that the statute was intended to express "moral disapproval of homosexuality." 153

\footnotetext{
147 Town of Greece v. Galloway, 134 S. Ct. 1811, 1826 (2014).

148 U.S. v. Windsor, 133 S.Ct. 2675, 2696 (2013).

149 Id at 2707 (Scalia, J, dissenting).

150 U.S. v. Windsor, 133 S.Ct. 2675, 2696 (2013).

151 Brian Soucek, The Return of Noncongruent Equal Protection, 83 FordHam L. REV. 155, 170 (2014).

152 United States v. Windsor, 133 S. Ct. 2675, 2693 (2013).

153 Id. at 2693.
} 


\section{UNCONSTITUTIONALLY ILLEGITIMATE DISCRIMINATION}

The Windsor Court, in my view, did not focus on the harm to victims, but rather emphasized the illegitimacy of federal action. The majority did not carefully describe the "arguments put forward" by DOMA's defenders, as Justice Scalia emphasized in his dissent, while instead noting the very title of the statute and its operation sought to deprive individuals of rights based on group membership. More troubling to Justice Scalia, the majority did not state whether the claim at issue was an equal protection claim or a due process claim. ${ }^{154}$ But if illegitimate discriminatory intent made any supposedly neutral justifications unsupported, then Congress did not legitimately legislate in the first place, under either constitutional theory. As a result, the standard of review for the plaintiff's claim was less important than the Government's lack of a credible defense.

Thus, the Windsor majority concluded its opinion stating that both the Fifth and Fourteenth Amendments "withdraw[]" from the Government "the power to degrade or demean" individuals. ${ }^{155}$ That last statement captures well the legitimacy-based approach advanced here. Whether it is conceived as an external constraint imposed by the Fifth and Fourteenth Amendments, or as a lack of internal government power, the result is that the government simply lacks the power to act out of an intent to discriminate against groups.

\section{B. Promoting Nondiscriminatory Government}

The impact of a finding if intentional discrimination can be to declare Government action illegitimate and beyond the power of Government to act in the first place. As described in Part I, the degree and type of proof of intent required to show that the Government has been sufficiently delegitimized by intentional discrimination may depend on the claim involved. What is clear, though, putting to one side questions regarding how to prove discriminatory intent, is that it matters in this analysis for the government to make a neutral statement of the purpose of its action. Many have criticized this feature of intent doctrines for sound reasons. 156 Such intent doctrines can encourage benign window-dressing or insincere

\footnotetext{
154 Id. at 2706-7 (Scalia, J. dissenting).

155 Id. at 2695.

156 See, e.g. Joel W. Friedman, The Burger Court and the Prima Facie Case in Employment Discrimination Litigation: A Critique, 65 CoRnell L. REv. 1, 13 (1979) (arguing that "discrimination can result from a combination of neutral policies and a tradition of societally imposed inequity."); David A. Stephen, True Lies: The Role of Pretext Evidence Under Batson v. Kentucky in the Wake of St. Mary's Honor Center v. Hicks, 94 Mich. L. REV. 488 (1995); Purkett v. Elem, 514 U.S. 765, 773 (Stevens, J. dissenting) (arguing that the race-neutral explanation doctrine adopted by the majority made the doctrine a "meaningless charade," where a prosecutor can readily offer "neutral explanations' which bear facial legitimacy but conceal a discriminatory motive.").
} 


\section{UNCONSTITUTIONALLY ILLEGITIMATE DISCRIMINATION}

statements of non-discrimination that disguise very real discrimination. 157 Indeed, the Supreme Court has noted in some contexts that such neutral reasons need not be "persuasive, or even plausible," since they are only serving the goal of assuring some facial validity of the government action, and will be tested only when the burden shifts back to the plaintiff to show that the reason offered was pretextual and that the government's motive was to discriminate. 158 Having offered some stated neutral purpose for government action, it make take egregiously disparate patterns of enforcement, like in Yick Wo, to provide plaintiffs with a winning claim.

There is an under-appreciated benefit to the weight that doctrine places on the presumption that the Government does not act with discriminatory intent when Government states it acts with nondiscriminatory intent or offers a facially valid reason for its actions. To be sure, it can encourage not even plausible reasons. However, the benefit is this: if one of the goals of constitutional doctrine is to strongly discourage the government from making intentionally discriminatory claims that disparage groups, then that presumption is a useful one. It gives government actors strong incentives not to act in a disparaging way. It gives government actors reasons to frame their conduct in non-disparaging ways. While those statements may not always be plausible, and while they may be mere window dressing in some settings, to encourage neutral and non-discriminatory window dressing does serve and important function.

Indeed, that presumption may be at work in a range of government policies and rules of conduct. For example, many government bodies have policies regulating what employees can say on social media, to try to avoid the corrosive impact it would have if a firefighter or police officer or other city official made derogatory statements. The New York City Police Department, for example, has adopted highly restrictive rules. ${ }^{159}$ Intent doctrine has that effect of encouraging government to constrain and try to prevent such discriminatory statements in its actions and its policymaking.

${ }^{157}$ For a discussion in the context of race discrimination in jury-selection claims, see, e.g. Charles J. Ogletree, Just Say No!: A Proposal to Eliminate Racially Discriminatory Uses of Peremptory Challenges, 31 AM. CRIM. L. REV. 1099, 1124-25 (1994). For a detailed discussion of this problem in the context of employment discrimination cases, see Sheila R. Foster, Causation in Antidiscrimination Law: Beyond Intent Versus Impact, 41 Hous. L. REV. 1469, 1515-16 (2005).

158 See, e.g. Purkett v. Elem, 514 S. Ct. 765, 767 (1995). See also Reeves v. Sanderson Plumbing Prods., Inc., 530 U.S. 133, 143 (2000) (describing analysis in which plaintiff must show that the employer's "proffered explanation" is pretext and that the motive was race discrimination, in an employment discrimination case); See St. Mary's Honor Ctr. v. Hicks, 509 U.S. 502 (1993) (same); Miller-El v. Dretke, 545 U.S. 231, 239 (2005) (explaining analysis in context of jury selection).

159 Police Dept. Sets Rules for Officers' Use of Social Media, The New York Times, March 28, 2013, at www.nytimes.com/2013/03/29/nyregion/new-york-police-dept-issues-guidelines-forsocial-media.html. 


\section{UNCONSTITUTIONALLY ILLEGITIMATE DISCRIMINATION}

The presumption of non-intent is not always easy to overcome, to be sure. It is a presumption, after all. The Supreme Court has explained that "[T] he Court often . . . accept[s] governmental statements of purpose, in keeping with the respect owed in the first instance to such official claims." 160 Similarly, the Supreme Court cited in Palmer v. Thompson to an evidentiary concern making it "extremely difficult" to look outside official statements, in the context of legislative decisions by multi-member bodies. ${ }^{161}$ In that case, the Justices accepted a factual finding by the lower court of a purpose to not covertly operate segregated pools, but to shut down pools due to "avoid violence and economic loss." 162 Since then the Court has been quite clear that evidence of discriminatory intent is not too "difficult or impossible" to assess, but is in fact a required aspect of the inquiry, in Fourteenth Amendment cases, and in other cases, such as First Amendment and Sixth Amendment cases. Palmer is a troubling case. But it was a case in which the Justices concluded the factual findings were mixed (and if the fact-finding was incorrect, the Supreme Court did not revisit the facts).

In other rulings, the Supreme Court has understandably highlighted opposing evidentiary concerns. People do not normally admit their motivation by unconstitutional bias and that "smoking gun" evidence does not always exist. In its Sixth Amendment ruling in Pena-Rodriguez, the Court described an evidentiary concern with racially derogatory remarks. The Court explained how: "[t]he stigma that attends racial bias may make it difficult for a juror to report inappropriate statements during the course of juror deliberations." 163 This important evidentiary concern makes it all the more important to remedy such explicit statements of discriminatory intent when they do come to light.

To provide another example in recent and high-profile litigation, in the Ninth Circuit ruling in the Travel Ban litigation, Judge Kozinski dissented, arguing that proving intent to discriminate involves "hopeless[]" weighing of "imponderables" and constitutes "precisely the kind of "judicial psychoanalysis' that the Supreme Court has told us to avoid. ${ }^{164}$ Judge Kozinski was right that the Court presumes that the Government acts with non-discriminatory intent. Judge Kozinski emphasized the Supreme Court noted in Hamdan that it has not "deferred to comments made by [government] officials to the media" when evaluating executive action, but that ruling did not address any claim of discriminatory intent. ${ }^{165}$ Similarly, Judge Kozinski emphasized the "presumption of regularity" that attaches to

\footnotetext{
160 McCreary, 545 U.S. at 865.

${ }^{161}$ Palmer v. Thompson, 403 U.S. 217, 224 (1971).

162 Washington v. Davis, 426 U.S. 229 (1976).

163 Pena-Rodriguez v. Colorado, 137 S.Ct. 855, 867 (2017).

164 Washington v. Trump, 858 F.3d 1168 (9th Cir. 2017) (quoting McCreary County v. ACLU of Ky., 545 U.S. 844, 862 (2005)).

165 Hamdan v. Rumsfeld, 548 U.S. 557, 623-24 n.52 (2006).
} 


\section{UNCONSTITUTIONALLY ILLEGITIMATE DISCRIMINATION}

federal officials' actions. ${ }^{166}$ However, no such presumption attaches when there is evidence of discriminatory intent or purpose. That is what the plaintiffs alleged in the Travel Ban litigation, making the presumption of regularity not as relevant. It is a commonplace that evidence of discrimination can shift the burden to the government to explain why its action was not infected with a discriminatory purpose. Indeed, as discussed next, in an important set of cases, evidence of discriminatory intent or purpose does more: it may deprive the government of the power to act at all.

\section{Undermining Government Power}

In a range of areas in which Congress legislates and Executive actors enforce, the relevant power arises from structural principles or powers implied from the structure of the Constitution. Courts have elaborated those powers, but they are not unlimited, including because other constitutional constraints may apply. The argument that I hope to advance here is that discriminatory intent doctrines do not just create individual rights, but they affect structural power as well. The federal government may not be authorized to act within its structural power in a way that exhibits in constitutionally illegitimate intent. Whether that is viewed as an external constraint on government power or an internal limit on that power, the result is that discriminatory intent can undermine government exercise of power.

An important example is the immigration power. There is no Article I federal immigration power; the "plenary" power of immigration matters was implied from a set of provisions by the Supreme Court in the late-Nineteenth Century. ${ }^{167}$ However, as the Supreme Court put it in Chadha, Congress and the Executive must "cho[ose] a constitutionally permissible means of implementing" their authority over immigration. ${ }^{168}$ That power is "subject to important constitutional limitations," including due process and habeas corpus. ${ }^{169}$ In a set of cases, the Court has asked whether the Government has a "facially legitimate and bona fide" reason for denying entry to the United States. ${ }^{170}$ Courts will be unlikely to find the Government interest to be legitimate, however, if there is evidence that the Government acted with unconstitutionally illegitimate intent. Another way to characterize the concern is that the Government is not properly acting with its power in such a case. Rather than view evidence of ill intent as undermining a defense to a

166 United States v. Chem. Found., Inc., 272 U.S. 1, 14-15 (1926).

167 Boutilier v. INS, 387 U.S. 118, 123 (1967) ("Congress' 'plenary power to make rules for the admission of aliens and to exclude those who possess those characteristics which Congress has forbidden."').

168462 U.S. at 941.

169 Zadvydas v. Davis, 533 U.S. 678, 695 (2001),.

170 Kerry v. Din, 135 S. Ct. at 2139-40 (Kennedy, J., concurring in the judgment); Fiallo v. Bell, 430 U.S. 787 (1977). 


\section{UNCONSTITUTIONALLY ILLEGITIMATE DISCRIMINATION}

plaintiff's claim, one can view the Government as having exceeded limits on its structural power. On that view, legitimacy defines government power.

The Supreme Court's reasoning in Kerry v. Din is an amalgam of these types of approaches: the defense-undermining and the power-limiting. In Din, in the controlling opinion regarding a challenge to denial of a visa, Justice Kennedy explained that where a plaintiff makes "an affirmative showing of bad faith" if it is "plausibly alleged with sufficient particularity," courts may then ask whether it is "facially legitimate" in fact by looking "behind" the challenged denial. Following Din, lower courts have similarly scrutinized government action in the immigration context where the plaintiff alleges racial bias. ${ }^{171}$

The immigration-ban executive order litigation brought out the importance of this caselaw in ways that many had not appreciated before. Thus, the Fourth Circuit, in its ruling on the immigration-ban executive orders, held "Where plaintiffs have seriously called into question whether the stated reason for the challenged action was provided in good faith, ... we step away from our deferential posture and look behind the stated reason for the challenged action." However, that panel noted, "We ... have minimal guidance on what "look[ing] behind" a challenged immigration action entails," since courts have not confronted the situation in which plaintiffs had alleged with particularity bad faith government at an executive-action level. Unfortunately, courts have now had to confront that issue squarely, and they may continue to do so in the future. That said, in response to these rulings, the Administration rescinded, twice, its executive orders. Statements that reflected religious and ethnic bias were retracted.

Perhaps government do-overs, following findings of unconstitutional intent, can paper over individious intent. They also have an important effect-the law of intentional discrimination encouraged the Government to re-do its actions in a more legitimate way. That is a good thing. When that should be enough to preserve the ability for Government to obtain a policymaking do-over, despite acting with expressed discriminatory intent, is the question to which I turn in the next Part.

\section{REMEDYING THE EFFECT OF INTENT}

This Part turns to the question what happens when the hammer drops: when a court finds unconstitutionally illegitimate discrimination, what are the consequences for government? Can a court order a do-over, like in a criminal trial tainted by a racist juror? If the same government officials respond to a court order finding a policy unconstitutional by re-enacting it, have they cured the taint, by simply disclaiming any discriminatory intent? When faced with discriminatory intent, courts have often dug in and imposed

171 Cardenas, 826 F.3d at 1173. 


\section{UNCONSTITUTIONALLY ILLEGITIMATE DISCRIMINATION}

searching and lasting remedies. As in Hunter $v$. Underwood, the passage of time, even decades, may not be a barrier to relief. However, the hypothetical posed in the Introduction raises the question whether the passage of time, combined with a re-enactment of a provision by new decisionmakers, is a barrier to relief. On one view, judges should incentivize do-overs, to encourage policymakers to re-do policy without evidencing discriminatory intent. However, I suggest that judges should still remain skeptical of certain do-overs, particularly because of the breadth of the harm that discriminatory intent has on society. Courts may be reluctant to find discriminatory intent, and they may be quick to presume neutral motivations for government actors, but when that intent is found, I argue that demanding remedies should be imposed corresponding to the severity of the cost to the legitimacy of government.

\section{A. Persistence of the Effect}

For how long does unconstitutionally illegitimate intent taint official action? How long is the relevant action de-legitimized? In general, the Supreme Court viewed the legacy of race segregation and other pervasive and intentional forms of discrimination as deep-rooted and requiring many years, indeed decades, to redress. The desegregation decisions took many decades to implement. Massive resistance resulted in countless types of government action struck down as an effort to evade race desegregation orders. Thus, when the Arkansas legislature gave the Governor the power to close all schools in 1958-59, to prevent desegregation in Little Rock public schools, the federal courts struck that law down, and then an effort by the school board to transfer its schools to a private, segregated school, and a "freedom of choice" plan designed to maintain segregation. ${ }^{172}$ Over time, the Supreme Court limited the scope of remedies and reversed inter-district remedies where de jure violations were demonstrated in only one district, as well as limiting the scope and nature of remedies as findings of intentional discrimination receded. ${ }^{173}$ Whether that was appropriate raises the question whether the focus should be on the immediate persons harmed by the discrimination, or as I have argued, on the broader harm to groups, society, and government.

That said, the Supreme Court has said arguably inconsistent things about this question of persistence of the taint of intentional discrimination.

172 Aaron v. McKinley, 173 F.Supp. 944 (E.D. Ark. 1959); Aaron v. Cooper, 261 F.2d 97 (8th Cir. 1958); Clark v. Board of Educ., 426 F.2d 1035 (8th Cir. 1970); for a description of the history of this litigation and problems with compliance ongoing in the 1980s, see Little Rock School Dist. v. Pulaski County Special School Dist. No. 1, 738 F.2d 82 (8th Cir. 1984).

${ }^{173}$ For decisions affirming broad remedial powers, see Keyes v. School Dist., 413 U.S. 189, 198-203 (1973) and Swann v. Charlotte-Mecklenburg Bd. of Educ., 402 U.S. 1, 16-18 (1970); for decisions limiting those powers, see, e.g. Milliken v. Bradley, 418 U.S. 717 (1974); See Missouri v. Jenkins, 515 U.S. 70 (1995); Freeman v. Pitts, 503 U.S. 467 (1992). For an excellent overview, see James E. Ryan, Schools, Race, Money, 109 YALE L. J. 249, 283 (1999). 


\section{UNCONSTITUTIONALLY ILLEGITIMATE DISCRIMINATION}

In its 1971 ruling in Palmer $v$. Thompson, the Justices, faced with the different question whether to reocgonize a violation in the first place, said:

[T] here is an element of futility in a judicial attempt to invalidate a law because of the bad motives of its supporters. If the law is struck down for this reason, rather than because of its facial content or effect, it would presumably be valid as soon as the legislature or relevant governing body repassed it for different reasons. ${ }^{174}$

As noted, however, that ruling predated modern Equal Protection law in which purpose or intent is a central part of the inquiry. Moreover, in Hunter $v$. Underwood, the Supreme Court held that the racially discriminatory effect persisted, though conditions had changed, for more than eighty years. ${ }^{175}$ Or as Justice Holmes has put it: "[I]t would be a new doctrine in constitutional law that the original invalidity could be cured by an administration which defeated their intent." ${ }^{176}$ As amicus law professors put it in the Travel Ban case: "Could a candidate run an explicitly racist campaign, win an election, enact facially neutral measures that distinctively injure the racial minority he had attacked for months, and then prevail against an equal protection challenge? Surely not." 177

Another way in which taint can dissipate is if conditions do change. In Shelby County, the Court emphasized how new voting rights data was not supplied by Congress and that "current conditions" regarding race discrimination in voting were not as dire as those which Congress was responding to when enacting the Voting Rights Act in the 1960s. ${ }^{178}$ Whether that empirical case is right, or misplaced as the dissenters strongly emphasized in the case, the Court was taking a long view of the role that anti-discrimination legislation should play. Unfortunately, the Justices vision that progress is largely complete and intentional discrimination a thing of the past may be naïve. The reasoning in Shelby County supports the view that discriminatory taint may take years to redress.

\section{B. Remedies for Discrimination}

Constitutional standing and remedies is sometimes cabined based on the judicial conception of the scope of the injuries to particular plaintiffs. Doctrines of Article III standing include remedial limits that can be tailored to the particular harms suffered by particular plaintiffs. ${ }^{179}$ The focus in this

\footnotetext{
174 Palmer v Thompson, 403 US 217 (1971).

175471 U.S. 222, 232 (1985).

176 Giles v. Harris, 189 U.S. 475, 487 (1903).

177 Amicus brief, supra, at *20.

178 Shelby County v. Holder, 133 S.Ct. 2612, 2631 (2013).

179 Los Angeles v. Lyons, 461 U.S. 95 (1983).
} 


\section{UNCONSTITUTIONALLY ILLEGITIMATE DISCRIMINATION}

article on the larger cost to government legitimacy, suggests that some of those remedial limitations are not as well supported. I have separately argued that Article III standing doctrine in fact reflects such a view, treating intentional discrimination claims differently because they involve groupbased harm and not individual harm. ${ }^{180}$ The theory advanced in this article helps to explain why and it suggests that standing might be based on still more than group-based harm, but also the broader cost to government legitimacy. That theory of Article III injury-in-fact is beyond the scope of this Article. ${ }^{181}$ The systemic or structural scope of the cost identified in this Article also suggests that not just Article III standing, but remedies should often be conceived as broader and longer-lasting than is sometimes the case. If the broader cost to government legitimacy persists, then remedies may be justified even if the harm directed at the particular plaintiffs is remedied. Then again, broader cost to government legitimacy may be less concrete and particularized than the types of injuries that the Court has emphasized in its Article III standing injuries. If so, then there is a deep tension in constitutional doctrine between the costs identified as most fundamental, and the injuries that produce an Article III "Case and Controversy."

The above discussion is related to the question of how to remedy intentional discrimination when it is identified. John Hart Ely prominently made the argument that it is a good thing to encourage the Government to cure any constitutional invalidity. Ely wrote:

"[S] uppose from time to time an action previously invalidated for unconstitutional motivation is retaken and upheld: so what? We don't regard the system as having failed when a person whose conviction was reversed because the jury was biased is reconvicted by a jury on remand: indeed we regard it as vindicated." 182

\footnotetext{
180 Brandon L. Garrett, Standing While Black: Distinguishing Lyons in Racial Profiling Cases, 100 Colum. L. REV. 1815 (2000).

181 One question would be whether a case like Allen v. Wright, 468 U.S. 737 (1984), in which the Supreme Court denied relief to plaintiffs seeking relief based on diminished ability of their children to receive an education in a racially integrated school, could instead proceed based on a theory not based on harm to education outcomes, but rather implicated government legitimacy to favor discriminatory private schools through tax treatment. Perhaps such a theory would be viewed unfavorably as a "generalized grievance," and not of the type sufficiently concrete to satisfy Article III standing requirements. See, e.g. Valley Forge Christian Coll. v. Ams. United for Separation of Church and State, Inc., 454 U.S. 464, 474 (1982) (finding lack of taxpayer standing); DaimlerChrysler Corp. v. Cuno, 547 U.S. 332, 345-46 (2006). To the extent that any "generalized grievance" concern is prudential and viewed apart from the injury-in-fact requirement, then perhaps the theory advanced in this Article supports relaxing that prudential concern in situations involving discriminatory intent. Craig Stern, Another Sign from Hein, 12 LEWIS \& ClaRK L. REV. 1169, 1214 (2008). Arguably, that is exactly what courts, including the Supreme Court, have done, including in voting rights cases involving discrimination claims. Garrett, supra note 165.

182 Ely, Democracy and Distrust, supra note xxx, at 139.
} 


\section{UNCONSTITUTIONALLY ILLEGITIMATE DISCRIMINATION}

We allow and indeed require a trial do-over to "cure" error at a criminal trial. We regard the new trial as an independent event; one reason why is that there is a new jury and therefore an entirely fresh decisionmaker.

The criminal law analogy is not on point when one is examining legislative or regulatory decisions. If there is not just a single criminal trial to do-over, but rather a city council or Congress, or a Governor or President who must re-issue legislation or executive action or regulation or voting districts, then the stakes are higher and the decionmakers may be the same who reached the prior decision in an intentionally discriminatory manner. Absent a new slate of decisionmakers, there are concerns with incentivizing not very credible disavowals of previously shared discriminatory intent. Matthew Adler has argued that when one conceives the constitutional right as one relating to rules, then the court's role is not to provide an optimal cure to a given plaintiff, but rather to "trigger the complete repeal" of an unconstitutional rule. ${ }^{183}$ That remedy does not answer the question, however, of whether the do-over itself is enough.

Moreover, the separate utility-based concern is raised that good and socially useful policy may have to be redone, to repair the cost to legitimacy caused by the discriminatory intent relevant actors. A do-over can be very much worth the social cost imposed. If an entirely new set of government actors, absent any of the biased former members, enacts a statute then perhaps the taint has been cured. If the same decisionmakers act, however, the corrosive effect of discriminatory intent or purpose may be so great that the taint persists and disables their ability to easily make policy in that area. That may be a real cost. Perhaps the cost of outright discriminatory statements by government is so great that the consequences must be severe.

I have argued in this Article that courts should be open, and in many contexts they have been, to the view that broader cost to government legitimacy may justify disabling potentially good policy adopted with invidious motives. In the long run, this strongly incentivizes nondiscriminatory policy and avoiding the need to interfere in policymaking.

\section{Anti-Discrimination Statutes}

The problems described in this Article extend from constitutional settings to statutory settings. In a range of statutory contexts, judges balance evidence of intentional discrimination as against the justifications offered by the government (or, more common in statutory contexts, a private employer). ${ }^{184}$ Thus, in Reeves $v$. Sanderson Plumbing "additional evidence of

\footnotetext{
${ }^{183}$ Adler, supra note xxx, at 129.

184 Under Section 8(a)(3) of the National Labor Relations Act, "the intention was to forbid only those acts that are motivated by an antiunion animus." Metropolitan Edison v. NLRB,
} 


\section{UNCONSTITUTIONALLY ILLEGITIMATE DISCRIMINATION}

age-based animus" provided sufficient evidence for the jury to find that respondent had "intentionally discriminated" under the ADEA. ${ }^{185}$ Or in Price Waterhouse v. Hopkins, Justice Sandra Day O'Connor concurred, noting "direct evidence of discriminatory animus" played a role in the analysis. 186 The Court did not use the term "animus," but instead referred to how "remarks at work that are based on sex stereotypes do not inevitably prove that gender played a part in a particular employment decision."187

Far more broadly, the Supreme Court has held that antidiscrimination statutes must be tailored to the scope of the targeted discrimination. In Shelby County v. Holder, the Court held that the preclearance requirements of Section 5 the Voting Rights Act were no longer constitutionally justified: "Our country has changed, and while any racial discrimination in voting is too much, Congress must ensure that the legislation it passes to remedy that problem speaks to current conditions." 188 Section 2 of the Voting Rights Act forbids election laws with a racially discriminatory effect or that were enacted with discriminatory intent. ${ }^{189} \mathrm{~A}$ raft of voter ID laws enacted across the country have resulted in litigation across the country concerning discriminatory intent as well as impact. 190

For example, the Supreme Court in Cooper v. Holder affirmed a trial court ruling that a North Carolina law regarding districting was intentionally discriminatory based on race, citing to findings that this was a "textbook example" of race-based districting, where uncontested evidence showed that the district line-drawers established a target that the district in question should be "a majority black district." 191 The State had countered that it had tried to "pack" the district not with black voters, but with Democrats; this was a partisan and not a race-based gerrymander. ${ }^{192}$ The Court affirmed the trial judges' ruling, but noted that it takes a "sensitive inquiry" into "circumstantial and direct evidence of intent." 193

Another trial judge, perhaps, could have ruled differently, and accepted the State's reason for drawing this voting district. That raises the criticism, again, that a central problem for discriminatory intent doctrines is that government (or private defendants) have incentives to offer neutral and non-discriminatory reasons for their conduct. Those reasons will be deferred

460 U.S. 691, 700 (1983); e.g., NLRB v. Great Dane Trailers, Inc., 388 U.S. 26, 33 (1967); NLRB v. Brown, 380 U.S., at 286-287.

185 Products, Inc., 530 U.S. 133, 153-54 (2000).

186490 U.S. 228, 271 (1989) (O’Connor, J., concurring).

187 Id. at 251.

188 Shelby County v. Holder, 133 S.Ct. 2612, 2631 (2013).

18952 U.S.C. $\S 10301(a)$.

190 Some voter identification-related laws have been struck down on discriminatory effects grounds. See, e.g. Florida v. U.S., 2012 WL 3538298 *47.

191137 S. Ct. $1455,1468-69$ (2017).

192 Id. at 1473.

193 Id. at 1473. 


\section{UNCONSTITUTIONALLY ILLEGITIMATE DISCRIMINATION}

to, at least to some degree, by judges. As a result, defendants that did in fact mean to discriminate, have strong reasons to express insincere but neutral reasons for their actions. Defendants also have strong reasons not admit to anything discriminatory in their actions in the first place. The underlying goal can be to disincentize illegitimate bases for decisionmaking. That is in itself an important goal, as I have argued in this Article.

Moreover, where decisionmaking was overly discriminatory in the past, courts may be more suspicious of policymaking, even if justified by neutral reasons. That overview of the role discrimination can play in statutes raises the same question discussed in this Article: what does evidence of discriminatory intent do to government defenses that it in fact acted based on legitimate reasons? The answer in many statutory contexts is the same as in constitutional contexts: is there in fact a legitimate reason for the action in question.

\section{Conclusion}

Intentional discrimination has long rested in an uneasy place in constitutional jurisprudence-but it deserves a far more central place in our jurisprudence and in our constitutional culture more broadly. ${ }^{194}$ Worrying about how many lawmakers in a multiple member body must have expressed unconstitutional intent to lead to a constitutional question is asking a question that is often beside the point. The approach that I have advanced is simple: When government makes disparaging remarks, this is strong evidence of discriminatory intent. In turn, discriminatory intent is enough to find government action unconstitutional.

In this Article, I have argued that judges and litigants should focus on legitimacy of Government action. The broad cost of discriminatory intent to legitimacy matters and should play an important role in addition to the harm, expressive or otherwise, that discriminatory intent causes to victims. It is not judicial review of derogatory remarks that is itself "divisive," but it is the failure to carefully review such actions that is costly and can lead to social division. ${ }^{195}$ As a matter of constitutional doctrine and sound theory, derogatory and motives should not enter into government. Indeed, for that reason, courts may be quite correct to not precisely define the minimum tolerable amount of invidious motives that government actors can espouse and still safely make policy. Government officials may be further deterred if unsure whether they can insulate policy from discriminatory motives. To be sure, if rules for proving intent are too difficult to satisfy, then constitutional

194 Robert C. Post, The Supreme Court, 2002 Term--Foreword: Fashioning the Legal Constitution: Culture, Courts, and Law, 117 HARV. L. REV. 4, 8 (2003) (on constitutional culture generally).

195 Steven D. Smith, The Jurisprudence of Denigration, 48 U.C. DAVIS L. REV. 675, 677 (2014) (arguing the Supreme Court's Windsor ruling consists in a "divisive" jurisprudence). 


\section{UNCONSTITUTIONALLY ILLEGITIMATE DISCRIMINATION}

enforcement will be ineffective. Critics have pointed out as much in the Batson v. Kentucky discrimination in jury selection context.

The cost of discrimination sweeps broadly and can disable and delegitimize government. Overdeterrence is not something we should worry about as much about as underdeterrence. Critics of intent tests have long argued that the focus of the doctrine should be on remedying actual harm and disparate impacts. I agree that disparate impacts should play an important role in discrimination claims, and that other values such as efficiency, federalism, and judicial capacity matter. With a focus on legitimacy of government action, however, one can observe that intent and purpose tests serve an additional purpose that is otherwise lost. Rather than serve an evidentiary role to ferret out intent, these doctrines serve a more fundamental purpose: to ensure government is strongly disincentivized from enacting illegitimate derogatory measures. That goal is not hollow. Intent and purpose tests serve a prophylactic purpose, to ward off government efforts to make policy out of a desire to disparage groups.

Discriminatory intent tests serve to protect legitimacy in government. While I have identified a range of areas in the doctrine that reflect this approach, judges have often not stated it clearly or directly. In part, this is for the good reason courts have often not had a reason to spell out the delegitimizing function that expressed discriminatory intent has on the Government. That unconstitutionally illegitimate intent has not often been litigated to its logical conclusion in the past is in part a testament to its effectiveness in disincentivizing government action that is openly discriminatory and derogatory. Moral disapproval or discriminatory intent directed against a group does far more than harm the group in one area of policymaking. It comes at a cost to the legitimacy of the government itself. For that reason, I argue, the disabling effect of such action on government may persist for some time. Unconstitutionally illegitimate intent can undermine government defenses or even structural power to act.

In this Article, I have argued that a legitimacy-focused approach both reflects constitutional doctrine and can improve it. As the Supreme Court put it in United States $v$. Windsor, the Constitution "withdraws" from the Government "the power to degrade or demean" individuals. 196 This approach strongly disincentivizes government action that disparages groups. Deterrence serves a Madisonian goal: to strongly incentivize government to act to "protect all parties, the weaker as well as the more powerful." 197 If in a society, the "stronger faction can readily unite and oppress the weaker," as James Madison wrote in Federalist 51, "anarchy may as truly be said to reign." 198 That is why the legitimacy-reinforcing function of discriminatory intent doctrine provides such a crucial bulwark for constitutional democracy.

196 Id. at 2695.

197 The Federalist No. 51, 324-25 (James Madison).

198 Id. 